\title{
Analisa dan Penerapan Sistem Inferensi Fuzzy Metode Mamdani untuk Penentuan Penerima Beasiswa
}

\author{
Munawaroh $^{1}$, Normalisa ${ }^{1}$, Alvino Octaviano ${ }^{1}$ \\ ${ }^{1}$ Program Studi Teknik Informatika, Fakultas Teknik, Universitas Pamulang. \\ Tanggerang Selatan, Indonesia.
}

Article History
Received:
20.01 .2019

Revised:
19.03 .2019
Accepted:
05.04.2019
*Corresponding Author:
Normalisa
Email:
dosen00377@unpam.ac.id

This is an open access article, licensed under: $\mathrm{CC}-\mathrm{BY}-\mathrm{SA}$

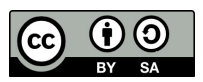

Abstrak: Beasiswa merupakan pemberian berupa bantuan keuangan yang diberikan kepada perorangan. Beasiswa bertujuan untuk digunakan demi keberlangsungan pendidikan yang ditempuh. SMAN 1 Parung merupakan lembaga formal milik pemerintah yang bergerak pada bidang pendidikan. SMAN 1 Parung mempunyai program beasiswa untuk siswa berprestasi yang kurang mampu. Masalah yang kerap kali terjadi yaitu tidak tepatnya pemberian beasiswa karena hanya menggunakan rata-rata nilai rapor. Berdasarkan masalah tersebut, penulis melakukan penelitian untuk menentukan penerima beasiswa menggunakan Sistem Inferensi Fuzzy metode Mamdani, dengan kriteria rata-rata nilai rapor, pendapatan orang tua, dan jumlah tanggungan orang tua. Pendekatan yang digunakan untuk menyelesaikan permasalahan penelitian melalui studi pustaka dari penelitian terdahulu tentang penentuan penerima beasiswa, teori tentang logika fuzzy metode Mamdani, kemudian menyusun tahap-tahap yang harus dilakukan dalam penelitian. Penerapan metode dan kriteri diharapkan dapat diperoleh perhitungan yang akurat sehingga menghasilkan penilaian yang akurat terhadap siswa-siswi yang berhak mendapatkan beasiswa.

Kata Kunci: Metode Mamdani, Pengambilan Keputusan, Sistem Inferensi Fuzzy.

Analysis and Application of the Mamdani Method Fuzzy Inference System for Determining Scholarship Recipients

Abstract: Scholarships are gifts in the form of financial assistance given to individuals. Scholarships aim to be used for the sustainability of the education being pursued. SMAN 1 Parung is a formal government-owned institution which is engaged in education. SMAN 1 Parung has a scholarship program for underachievers. A problem that often occurs is the inaccuracy of scholarships because they only use an average report card grade. Based on these problems, the authors conducted a study to determine the recipient of the scholarship using the Mamdani method of fuzzy inference, with criteria for the average value of report cards, parental income, and the number of dependent parents. The approach used to solve research problems through literature studies from previous research on the determination of scholarship recipients, the theory of fuzzy logic Mamdani method, then arrange the stages that must be done in research. The application of methods and criteria is expected to be obtained by accurate calculations so as to produce an accurate assessment of students who are entitled to scholarships.

Keywords: Decision Making, Fuzzy Inference System, Mamdani Method. 


\section{Pendahuluan}

Beasiswa adalah bantuan yang diberikan oleh pihak tertentu untuk perorangan yang digunakan demi keberlangsungan pendidikan yang ditempuh [1]. Hal yang mendasari mengenai beasiswa yaitu Undang-Undang Republik Indonesia Nomor 20 Tahun 2003 Bab V pasal 12 (1.c) yang menyebutkan bahwa setiap peserta didik pada setiap satuan pendidikan berhak mendapatkan beasiswa bagi yang berprestasi dan memiliki orang tua yang kurang mampu untuk membiayai pendidikannya. Pasal 12 (1.d) menyebutkan bahwa setiap peserta didik pada setiap satuan pendidikan berhak mendapatkan biaya pendidikan bagi siswa yang orang tuanya kurang mampu membiayai pendidikan. Selain itu, pasal 31(1) Undang-Undang Dasar 1945 menegaskan bahwa setiap warga negara berhak mendapatkan pengajaran. Berdasarkan pasal tersebut, pemerintah wajib memberikan kemudahan kepada masyarakat untuk mengenyam pendidikan yang berkualitas tanpa adanya diskriminasi sosial. Selain itu, penyelenggarakan pendidikan berkualitas diperlukan biaya yang cukup besar. Oleh karena itu, bagi setiap peserta didik pada setiap satuan pendidikan berhak mendapatkan biaya pendidikan. Hal tersebut diperuntukan bagi siswa yang memiliki orang tua tidak mampu secara ekonomi untuk membiayai pendidikan. Selain tidak mampu secara ekonomi, siswa juga harus memiliki prestasi untuk mendapatkan beasiswa.

SMAN 1 Parung merupakan lembaga formal milik pemerintah yang bergerak pada bidang pendidikan. SMAN 1 Parung mempunyai visi untuk mengembangkan siswa-siswi yang berprestasi pada semua bidang. Penerima beasiswa di SMAN 1 Parung ditentukan berdasarkan rata-rata nilai rapor. Permasalahan yang sering muncul pada pemberian beasiswa ini adalah sulitnya menentukan siswa yang berhak menerima beasiswa karena hanya menggunakan rata-rata nilai rapor, sehingga siswa-siswi yang nilai rata-rata rapornya tinggi berhak mendapatkan beasiswa. Oleh karena itu, maka perlu dilakukan penelitian yang akan membantu penentuan peserta didik yang berhak untuk mendapatkan beasiswa tersebut. Oleh sebab itu, permasalahan tersebut diharapkan dapat diselesaikan dengan menggunakan fuzzy inference system metode Mamdani untuk menentukan penerima beasiswa. Metode tersebut diharapkan dapat menghasilkan keputusan terbaik untuk penerima beasiswa berdasarkan kriteria-kriteria yang digunakan pada penelitian ini.

\section{Tinjauan Pustaka}

Penelitian mengenai Analisis dan Penerapan Fuzzy Inference System Metode Mamdani untuk Penentuan Penerima Beasiswa, mengacu pada penelitian sebelumnya yang telah dilakukan oleh Wibowo et al. [2] yang berjudul Sistem Pendukung Keputusan untuk Menentukan Penerima Beasiswa Bank BRI Menggunakan FMADM (Studi Kasus: Mahasiswa Fakultas Teknologi Industri Universitas Islam Indonesia). Pada penelitian tersebut diangkat suatu kasus yaitu mencari alternatif terbaik berdasarkan kriteria-kriteria yang telah ditentukan dengan mengggunakan metode Simple Additive Weighting (SAW) untuk perhitungan metode Fuzzy Multiple Attribute Decision Making (FMADM) pada kasus tersebut. Penelitian tersebut dilakukan dengan mencari nilai bobot untuk setiap atribut. Tahap selanjutnya dilakukan proses perankingan yang akan menentukan alternatif yang optimal yaitu mahasiswa terbaik yang akan menerima beasiswa. Penelitian selanjutnya dilakukan oleh Kusumadewi [3] dengan judul "Pencarian Bobot Atribut pada Multiple Attribute Decision Making (MADM) Dengan Pendekatan Obyektif Menggunakan Algoritma". Penelitian tersebut membahas tentang kasus seleksi calon dosen di Fakultas Teknik Informatika Universitas Islam Indonesia (FTI UII) dengan menggunakan algoritma genetika untuk mencari nilai bobot atribut melalui pendekatan obyektif. Langkah pertama penelitian tersebut adalah penetapan sejumlah alternatif dan beberapa atribut (kriteria). Tahap selanjutnya, pencarian bobot melalui pendekatan obyektif pencarian bobot dengan algoritma genetika. Tahap terakhir pada penelitian tersebut adalah proses pe-ranking-an. Selain itu, Hafsah [4] dengan judul "Sistem Pendukung Keputusan Pemilihan Jurusan di SMU dengan Logika Fuzzy “. Pada penelitian tersebut dikaji suatu kasus lembaga pendidikan seperti pendidikan SMU yang sering membutuhkan suatu bentuk keputusan pada saat memilih jurusan yang sesuai untuk siswasiswi SMU. Keputusan yang diambil ketika memilih jurusan mungkin hampir benar sesuai dengan kemampuan, bakat dan minat siswa atau mungkin juga salah.

\subsection{Beasiswa}

Beasiswa merupakan bantuan pendidikan yang diatur berdasarkan Undang-Undang yang berlaku di Indonesia. Selain itu, terdapat bermacam-macam beasiswa diklasifikasikan berdasarkan penyedia beasiswa dan peruntukannya. 
Beasiswa adalah penghasilan bagi yang menerimanya. Hal ini sesuai dengan ketentuan pasal 4 ayat (1) UU $\mathrm{PPh} / 2000$ yang menjelaskan pengertian penghasilan adalah tambahan kemampuan ekonomis dengan nama dan dalam bentuk apa pun yang diterima atau diperoleh dari sumber Indonesia atau luar Indonesia yang dapat digunakan untuk konsumsi atau menambah kekayaan Wajib Pajak (WP). Undang-Undang Republik Indonesia Nomor 20 Tahun 2003 Bab V pasal 12 (1.c) menyebutkan bahwa setiap peserta didik pada setiap satuan pendidikan berhak mendapatkan beasiswa bagi yang berprestasi dan memiliki orang tua yang kurang mampu membiayai pendidikannya. Pasal 12 (1.d) menyebutkan bahwa setiap peserta didik pada setiap satuan pendidikan berhak mendapatkan biaya pendidikan bagi mereka yang yang orang tuanya kurang mampu membiayai pendidikan. Beasiswa menjadi sarana bagi para pelajar maupun mahasiswa dengan kemampuan ekonomi terbatas namun ingin mengenyam pendidikan setinggi mungkin

Kategori Beasiswa menurut Buku Pintar Beasiswa, dari segi pendanaan yaitu beasiswa penuh dan beasiswa sebagian. Beasiswa sebagian (partial scholarship) adalah program beasiswa yang hanya menanggung biaya tertentu saja selama menjalani perkuliahan. Program tersebut biasanya banyak ditawarkan oleh pihak universitas atau untuk program pendidikan pendek (short/summer course). Macam-Macam beasiswa digolongkan berdasarkan pihak penyedia dan peruntukkannya. Beasiswa yang digolongkan berdasarkan pihak penyedia meliputi:

1. Beasiswa dari pemerintah,

2. Beasiswa dari pihak swasta,

3. Beasiswa dari negara maju, dan

4. Beasiswa komunitas.

Macam-macam beasiswa di golongkan peruntukannya meliputi:

1. Beasiswa penghargaan,

2. Beasiswa bantuan,

3. Beasiswa atletik, dan

4. Beasiswa penuh.

\subsection{Logika Fuzzy}

Logika fuzzy pertama kali diperkenalkan oleh Prof. Lotfi Zadeh seorang kebangsaan Iran yang menjadi guru besar di University of California at Berkeley pada tahun 1965. Pada kamus Oxford, istilah fuzzy didefinisikan sebagai blurred atau kabur dan imprecisely defined atau tidak presisi serta confused atau membingungkan. Istilah sistem fuzzy tidak dimaksudkan untuk mengacu pada sebuah sistem yang tidak jelas definisinya, cara kerjanya ataupun deskripsinya. Sistem fuzzy adalah sebuah sistem yang dibangun dengan definisi, cara kerja, dan deskripsi yang jelas berdasar teori fuzzy logic [5].

Logika fuzzy adalah suatu cara yang tepat untuk memetakan suatu ruang input ke dalam suatu ruang output (Kusumadewi \& Purnomo, 2004). Logika fuzzy sudah banyak diterapkan di pelbagai bidang baik di dunia industri maupun bisnis. Menurut Naba [5] alasan menggunakan logika fuzzy yaitu:

1. Konsep fuzzy logic sangat sederhana sehingga mudah dipahami. Kelebihannya dibandingkan konsep yang lain bukan pada kompleksitasnya, tetapi pada pendekatannya dalam memecahkan masalah.

2. Logika fuzzy merupakan konsep fleksibel yang dapat dibangun dan dikembangkan dengan mudah.

3. Logika fuzzy memberikan toleransi terhadap ketidak presisian data. Hal tersebut sangat cocok dengan fakta sehari-hari. Segala sesuatu di alam ini relatif tidak presisi.

4. Pemodelan/pemetaan untuk mencari hubungan data input-output dari sembarang sistem black-box bisa dilakukan dengan memakai sistem fuzzy.

5. Pengetahuan atau pengalaman dari para pakar dapat dengan mudah dipakai untuk membangun kosep fuzzy.

6. Logika fuzzy dapat diterapkan dalam desain sistem kontrol tanpa harus menghilangkan teknik desain sistem kontrol konvensional yang sudah terlebih dahulu ada.

7. Logika fuzzy berdasarkan pada bahasa manusia. 


\subsubsection{Himpunan Fuzzy}

Himpunan fuzzy adalah sebuah himpunan keanggotaan dari tiap elemennya tidak mempunyai batas yang jelas. Pada prinsipnya himpunan fuzzy adalah perluasan himpunan crisp. Himpunan tersebut yang membagi sekelompok individu kedalam dua kategori yaitu anggota dan bukan anggota. Pada himpunan crisp, nilai keanggotaan suatu item $\mathrm{x}$ dalam suatu himpunan A sering ditulis dengan $\mu \mathrm{A}[\mathrm{x}]$ yang memiliki 2 kemungkinan, yaitu:

1. Satu (1) yang berarti bahwa suatu item menjadi anggota dalam suatu himpunan.

2. Nol (0) yang berarti bahwa suatu item tidak menjadi anggota dalam suatu himpunan.

Pada himpunan crisp, nilai keanggotaan ada 2 kemungkinan yaitu 0 atau 1. Sedangkan pada himpunan fuzzy, nilai keanggotaan terletak pada rentang 0 sampai 1 . Ada beberapa istilah yang perlu diketahui dalam memahami sistem fuzzy, yaitu:

1. Variabel fuzzy,

2. Himpunan fuzzy,

3. Semesta Pembicaraan, dan

4. Domain fuzzy.

\subsubsection{Fungsi keanggotaan}

Fungsi derajat keanggotaan (membership function) adalah suatu kurva yang menunjukkan pemetaan titik-titik input data pada derajat keanggotaan yang memiliki interval antara 0 sampai 1 [6]. Salah satu cara yang dapat digunakan untuk mendapatkan nilai keanggotaan adalah dengan melalui pendekatan fungsi.

Ada beberapa fungsi yang bisa digunakan diantaranya:

1. Representasi linier,

2. Representasi kurva segitiga,

3. Representasi kurva trapezium,

4. Representasi kurva bentuk bahu,

5. Representasi kurva-S, dan

6. Representasi bentuk lonceng.

\subsubsection{Operator Fuzzy}

Jika G, H, A adalah himpunan fuzzy maka menurut Zimmermann [6] operator dasar himpunan fuzzy meliputi:

1. Operator AND

Hasil operator AND diperoleh dengan mengambil keanggotaan minimum antara himpunan fuzzy yang bersangkutan dan direpresentasikan dengan Persamaan (1):

$$
\forall G, H \subset A, x \in A, \quad \mu_{G \cap H}(x)=\min \left(\mu_{G}(x), \mu_{H}(x)\right)
$$

\section{Operator OR}

Hasil operator OR diperoleh dengan mengambil keanggotaan maksimum antar himpunan fuzzy yang bersangkutan dan direpresentasikan dengan Persamaan (2)

$$
\forall G, H \subset A, x \in A, \quad \mu_{G \cap H}(x)=\max \left(\mu_{G}(x), \mu_{H}(x)\right)
$$

\subsubsection{Fungsi Implikasi dan inferensi aturan}

Conditional fuzzy proposition merupakan bentuk relasi fuzzy yang ditandai dengan penggunaan pertanyaan IF yang secara umum dituliskan IF T is t THEN U is u. Proposisi yang mengikuti IF disebut anteseden sedangkan proposisi yang mengikuti THEN disebut konsekuen. Proposisi ini dapat diperluas dengan menggunakan operator fuzzy seperti pada Persamaan (3) [7]:

$\operatorname{IF}\left(x_{1}\right.$ is $\left.A_{1}\right) v\left(x_{2}\right.$ is $\left.A_{2}\right) v\left(x_{3}\right.$ is $\left.A_{3}\right) v \ldots\left(x_{N}\right.$ is $\left.A_{N}\right)$ THEN $y$ is $B$ dengan o adalah operator (Misal :OR atau AND) 
Menurut Kusumadewi [8] jika suatu proposisi menggunakan bentuk terkondisi maka ada dua fungsi implikasi secara umum yang dapat digunakan yaitu metode minimum $(\alpha-c u t)$ dan metode dot (scalling).

\subsubsection{Sistem Inferensi Fuzzy Metode Mamdani}

Metode Mamdani sering juga dikenal dengan nama metode min-max. Metode tersebut diperkenalkan oleh Ebrahim Mamdani pada tahun 1975. Menurut Roses et al. [9] ada empat tahapan untuk mendapatkan output meliputi:

1. Pembentukan himpunan fuzzy,

2. Aplikasi fungsi implikasi,

3. Komposisi aturan, dan

4. Penegasan (defuzzy)

\subsection{Matlab}

Matlab adalah bahasa pemrograman tingkat tinggi dengan arti perintah dan fungsi-fungsinya yang dapat dimengerti dengan mudah meskipun bagi seorang pemula [10]. Hal tersebut karena pada matlab, masalah dan solusi dapat diekspresikan dengan notasi-notasi matematis yang biasa digunakan.

Kegunaan umum dari matlab diantaranya:

1. Matematika dan komputasi

2. Pengembangan algoritma

3. Pemodelan dan simulasi

4. Pembuatan prototype

5. Analisis data

6. Eksplorasi

7. Visualisasi

8. Dan pengembangan aplikasi termasuk GUI

Matlab singkatan dari matrix laboratory, awalnya dibuat untuk menyediakan akses yang mudah untuk pengembangan software matriks pada proyek Linpack dan Eispack. Saat ini, matlab menggabungkan Lapack dan Blas library untuk komputasi matriks. Selain itu, matlab telah menjadi alat bantu standar instruksional pada perkuliahan pengenalan dan tingkat lanjut bidang matematika, teknik, dan sains.

Matlab memiliki toolbox yang memungkinkan pengguna bisa belajar dan menerapkan berbagai specialized technology. Beberapa bidang sudah tersedia toolboxnya pada matlab, meliputi logika fuzzy, sistem kontrol, dan pengolahan sinyal.

\section{Metode Penelitian}

Metode penelitian ini memiliki dua tahapan, yaitu tahap pengumpulan data dan tahap implementasi metode. Permasalahan penelitian ditentukan dari studi lapangan tentang kesulitan memilih siswa yang tepat untuk menerima beasiswa karena penentuan beasiswa ditentukan hanya dengan nilai rapor tanpa melihat sisi perspektif yang lain sehingga penerima beasiswa menjadi kurang tepat sasaran. Hal tersebut dikatakan sulit karena siswa yang mengajukan beasiswa cukup banyak dan banyak terdapat nilai yang sama sehingga apabila penentuan beasiswa hanya dilihat dari nilai maka hal tersebut akan mengakibatkan ketidakadilan bagi sebagian siswa. Oleh karena itu diperlukan analisa proses penentuan penerima beasiswa dengan logika fuzzy yang diharapkan dapat membantu pemberian beasiswa menjadi tepat sasaran. Jenis penelitian yang digunakan pada penelitian ini adalah model eksperimen. Penelitian eksperimen ini bertujuan untuk membuat penentuan penerima beasiswa berbasis logika fuzzy yang nantinya diharapkan dapat membantu mentukan penerima beasiswa sehingga tepat sasaran. Analisa Kasus ini dilakukan dengan menggunakan metode Mamdani.

\subsection{Metode Analisis Data}

Data primer pada penelitian ini adalah data yang diperoleh dari sumber-sumber asli. Sumber asli sebagai sumber pertama data tersebut diperoleh. Penelitian ini diasusmsikan bahwa variabel input adalah rata-rata nilai rapor, pendapatan, dan tanggungan orang tua, sedangkan variabel output adalah beasiswa. Variabel rata-rata nilai rapor merupakan hasil penjumlahan seluruh nilai rapor kemudian dilakukan pembagian dengan banyaknya bilangan yang ditambahkan. Variabel pendapatan merupakan pendapatan orang tua siswa selama satu bulan. Variabel tanggungan orang tua adalah 
banyaknya anak yang masih menjadi tanggung jawab orang tua. Variabel beasiswa adalah keluaran yang menentukan siswa tersebut layak mendapatkan beasiswa atau tidak. Identifikasi data merupakan awal dari metode analisis data. Identifikasi data dilakukan dengan penentuan variabel yang diperlukan untuk melakukan perhitungan dan analisis masalah. Perhitungan penentuan beasiswa dipengaruhi oleh beberapa faktor diantaranya :

1. Data rata-rata nilai rapor,

2. Data pendapatan orang tua siswa selama 1 bulan, dan

3. Data tanggungan orang tua siswa.

\section{Pembentukan Himpunan Fuzzy}

Pada metode Mamdani baik variabel input maupun variabel output dibagi menjadi satu atau lebih himpunan fuzzy. Metode Mamdani menekankan pada variabel dan semesta pembicaraan yang disajikan pada Tabel 1 .

Tabel 1. Variabel dan Semesta Pembicaraan

\begin{tabular}{cccc}
\hline Fungsi & Variabel & $\begin{array}{c}\text { Semesta } \\
\text { Pembicaraan }\end{array}$ & Keterangan \\
\hline \multirow{2}{*}{ Input } & Rata-rata nilai rapor & {$[70-83]$} & $\begin{array}{c}\text { Rata-rata nilai rapor selama 1 } \\
\text { semester }\end{array}$ \\
\cline { 2 - 4 } & Pendapatan & {$[0-3.500 .000]$} & $\begin{array}{c}\text { Pendapatan orang tua siswa } \\
\text { selama 1 bulan }\end{array}$ \\
\cline { 2 - 4 } & $\begin{array}{c}\text { Tanggungan Orang } \\
\text { Tua }\end{array}$ & {$[0-6]$} & $\begin{array}{c}\text { Jumlah anak yang masih menjadi } \\
\text { tanggungan orang tua }\end{array}$ \\
\hline Output & Beasiswa & {$[0-5]$} & $\begin{array}{c}\text { Skala kelayakan untuk } \\
\text { mendapatkan beasiswa }\end{array}$ \\
\hline
\end{tabular}

Hal terpenting pada penggunaan metode fuzzy adalah himpunan fuzzy yang merupakan suatu grup yang mewakili suatu kondisi atau keadaan tertentu pada suatu variabel fuzzy yang disajikan pada Tabel 2.

Tabel 2. Himpunan Fuzzy

\begin{tabular}{|c|c|c|c|c|}
\hline FUNGSI & VARIABEL & $\begin{array}{l}\text { HIMPUNAN } \\
\text { FUZZY }\end{array}$ & $\begin{array}{c}\text { SEMESTA } \\
\text { PEMBICARAAN }\end{array}$ & DOMAIN \\
\hline \multirow{9}{*}{ Input } & \multirow{3}{*}{$\begin{array}{c}\text { Rata-Rata Nilai } \\
\text { Rapor }\end{array}$} & Rendah & \multirow{3}{*}{ [70-83] } & 70,77 \\
\hline & & Sedang & & $73,77,80$ \\
\hline & & Tinggi & & 77,83 \\
\hline & \multirow{3}{*}{ Pendapatan } & Rendah & \multirow{3}{*}[0-3.500.000]{} & $0-1500.000$ \\
\hline & & Sedang & & 500ribu-2,5juta \\
\hline & & Tinggi & & 1,5 juta- 3,5 juta \\
\hline & \multirow{3}{*}{$\begin{array}{c}\text { Tanggungan Orang } \\
\text { Tua }\end{array}$} & Sedikit & \multirow{3}{*}[0-6]{} & $0-3$ \\
\hline & & Sedang & & $2-4$ \\
\hline & & Banyak & & $3-6$ \\
\hline \multirow{3}{*}{ Output } & \multirow{3}{*}{ Beasiswa } & Rendah & \multirow{3}{*}[0-5]{} & $1-2,5$ \\
\hline & & Sedang & & $1,5-4$ \\
\hline & & Tinggi & & $3,5-5$ \\
\hline
\end{tabular}


Semua variabel pada Tabel 2. Memiliki tiga himpunan fuzzy yang dapat diketahui fungsi keanggotaannya. Variabel yang digunakan meliputi variabel input dan output. Berdasarkan Tabel 2. dapat diketahui bahwa variabel rata-rata nilai rapor terdiri dari tiga himpunan meliputi:
1. Rendah
$=[70,77]$
2. Sedang
$=[73,77,80]$
3. Tinggi
$=[77,83]$

Himpunan fuzzy dapat digunakan untuk menyusun suatu fungsi keanggotaan yang memetakan suatu titik-titik input data pada derajat keanggotaan sehingga dapat dihasilkan suatu kurva yang disajikan pada Gambar 1.

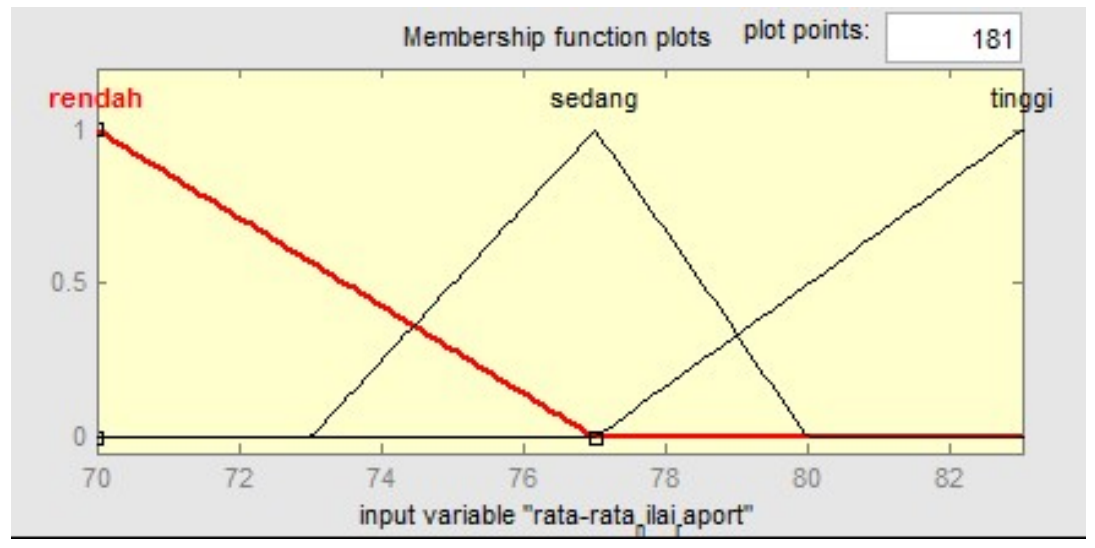

Gambar 1. Fungsi Keanggotaan Variabel Rata-Rata Nilai Rapor

Berdasarkan Gambar 1. dapat ditentukan ekspresi suatu fungsi keanggotaan. Fungsi keanggotaan himpunan fuzzy untuk variabel rerata nilai rapot dapat dilihat pada Persamaan (4)-(6):
$\mu_{\text {rendah }}[\mathrm{x}]:\left\{\begin{array}{l}(77-\mathrm{x}) / 7 \\ 0 ;\end{array}\right.$
$0 \leq x \leq 77$
$\mathrm{x} \geq 77$
$\mu_{\text {sedang }}[\mathrm{x}]:\left\{\begin{array}{l}0 ; \\ (\mathrm{x}-73) 44^{-} \\ (80-\mathrm{x}) 3 ;\end{array}\right.$
$x \leq 73$ atau $x \geq 80$
$73 \leq \mathrm{x} \leq 77$
$77 \leq \mathrm{x} \leq 80$
$\mu_{\text {tinggi }}[\mathrm{x}]:\left\{\begin{array}{l}0 ; \\ (\mathrm{x}-77) 65 ; \\ 1 ;\end{array}\right.$

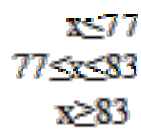

Variabel selanjutnya yang digunakan pada penelitian ini adalah variabel pendapatan yang termasuk variabel input. Variabel Pendapatan terdiri dari tiga himpunan meliputi:
1.
Tinggi $=[0,1.500 .000]$
2.
Sedang $=[500.000,1.500 .000,2.500 .000]$
3.
Rendah $=[1.500 .000,3.500 .000]$

Berdasarkan himpunan tersebut, dapat ditentukan fungsi keanggotaan dengan menggunakan suatu kurva yang disajikan pada Gambar 2. Gambar 2 menunjukan adanya tiga himpunan fuzzy berkaitan dengan tingkat pendapatan orang tua murid. Ekspresi untuk fungsi keanggotaan disajikan pada Persamaan (7)-(9):

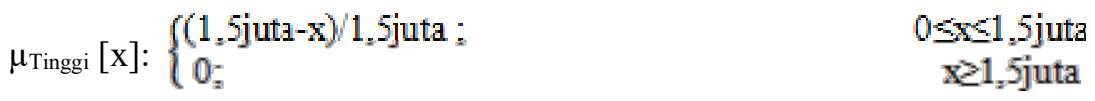


Munawaroh, Normalisa, Alvino Octaviano.

Analisa dan Penerapan Fuzzy Inference System Metode Mamdani untuk Penentuan Penerima Beasiswa.

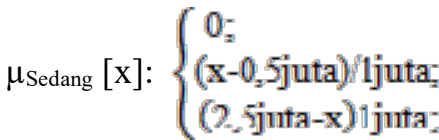

$\mu_{\text {Rendah }}[\mathrm{x}]:\left\{\begin{array}{l}0 ; \\ (\mathrm{x}-1,5 \mathrm{jta}) / 2 \mathrm{juta} \text { : } \\ 1 ;\end{array}\right.$

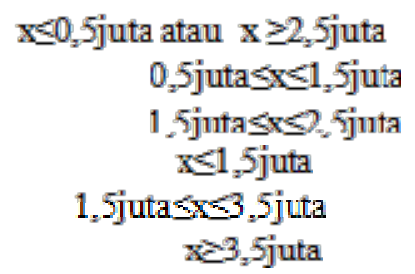

(8)

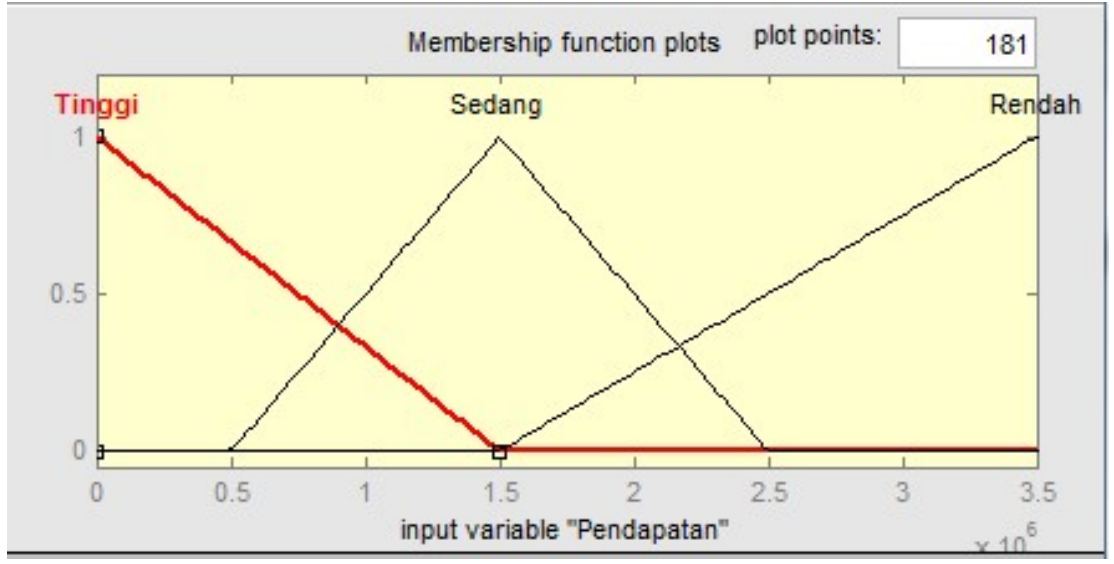

Gambar 2. Fungsi Keanggotaan Variabel Pendapatan

Variabel input terakhir yang digunakan pada penelitian ini adalah variabel tanggungan orang tua. Variabel ini menentukan tingkat kelayakan siswa penerima beasiswa. Variabel tanggungan orang tua terdiri dari tiga himpunan meliputi:
1. Rendah
$=[0,3]$
2. Sedang
$=[2,3,4]$
3. Tinggi
$=[3,6]$

Fungsi keanggotaan dari variabel tanggungan orang tua dapat dilihat pada Gambar 3.

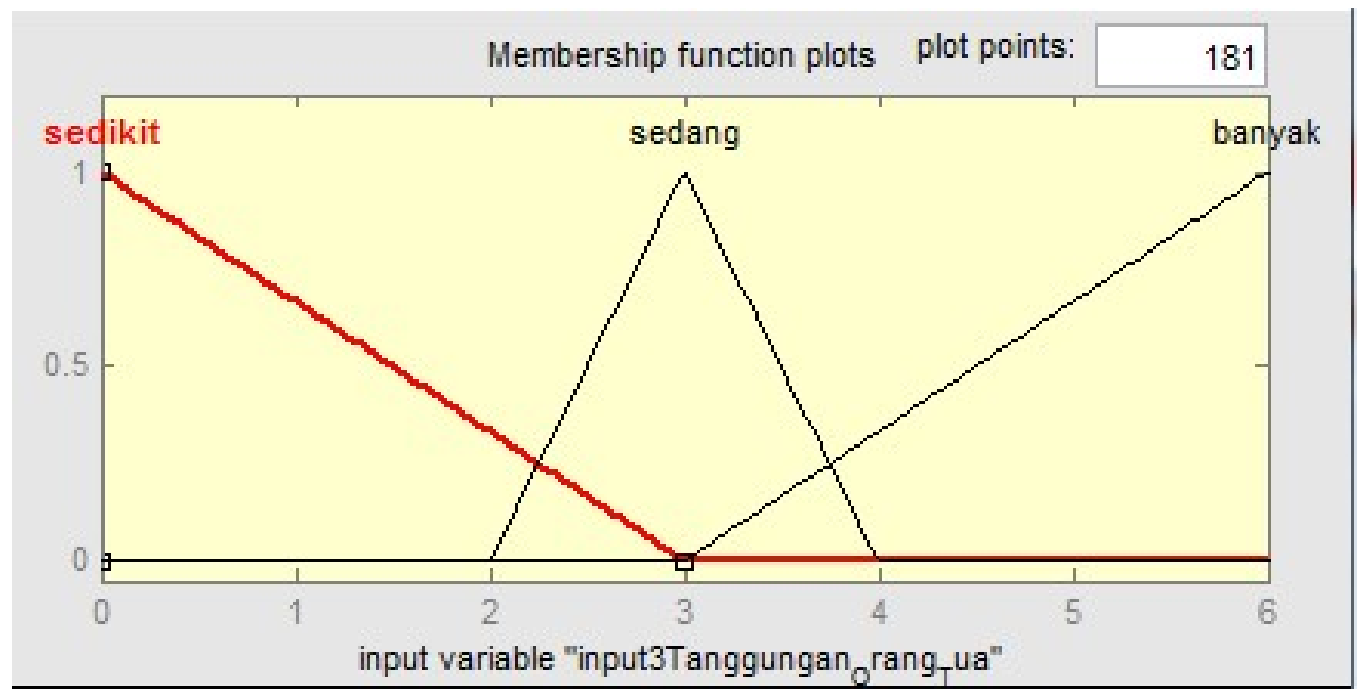

Gambar 3. Fungsi Keanggotaan Variabel Tanggungan Orang Tua 
Berdasarkan Gambar 3. dapat ditentukan ekspresi suatu fungsi keanggotaan. Fungsi keanggotaan himpunan Fuzzy untuk variabel rerata nilai rapot dapat dilihat pada Persamaan (10)-(12):
$\mu_{\text {sedikit }}[\mathrm{x}]:\left\{\begin{array}{l}(3-\mathrm{x}) / 3 \\ 0 ;\end{array}\right.$
$0 \leq x \leq 3$
$\mu_{\text {sedang }}[\mathrm{x}]:\left\{\begin{array}{l}0 ; \\ (\mathrm{x}-2) / 1 ; \\ (4-\mathrm{x}) 1 ;\end{array}\right.$
$x \geq 3$
$\mu_{\text {banyak }}[\mathrm{x}]:\left\{\begin{array}{l}0 ; \\ (\mathrm{x}-3){ }^{-} \\ 1,\end{array}\right.$
$\mathrm{x} \leq$. atal1 $\mathrm{x} \geq 4$
$2 \leq \mathrm{x} s$
$3 \leq \mathrm{x} \leq 4$

Pada penelitian ini, variabel output yang digunakan hanya satu jenis yaitu variabel beasiswa. Variabel beasiswa terdiri atas tiga himpunan meliputi:
1. Rendah $=[0,2.5]$
2. Sedang $=[1.5,3,4]$
3. Tinggi $=[2.5,5]$

Berdasarkan himpunan Fuzzy dari variabel beasiswa, maka dapat diketahui fungsi keanggotaan dari variabel beasiswa pada kurva yang disajikan pada Gambar 4.

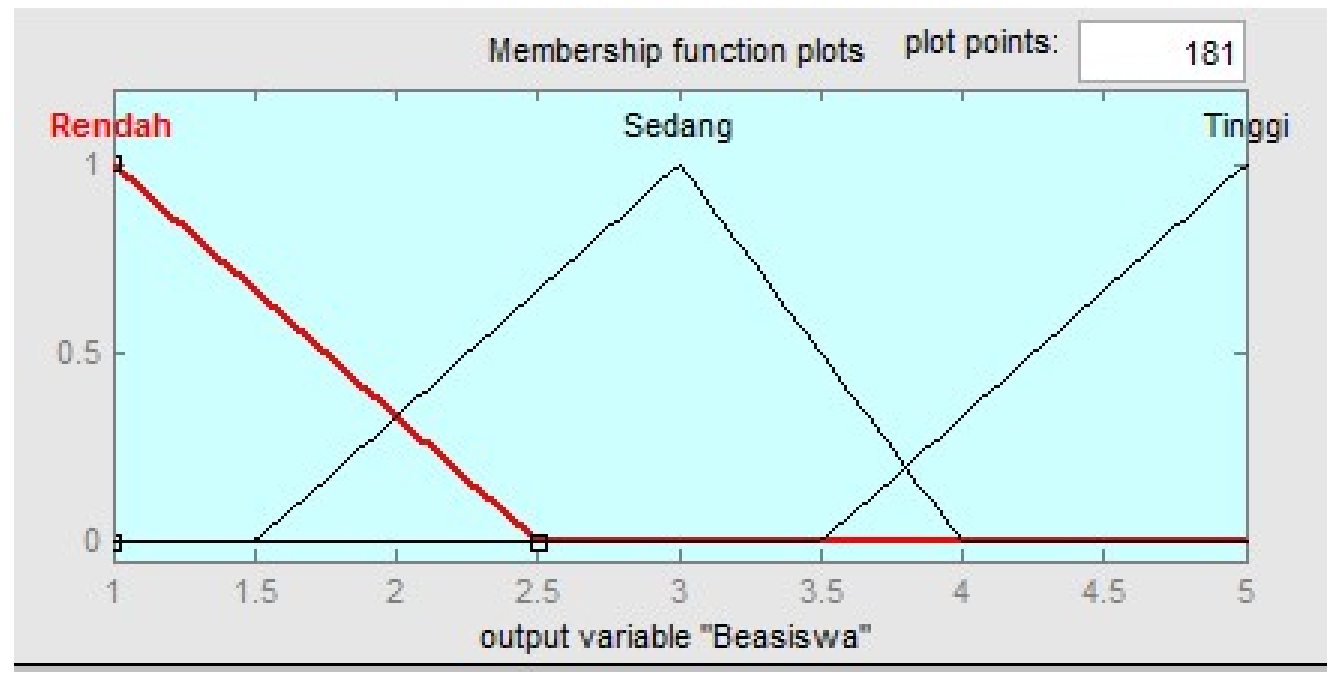

Gambar 4. Fungsi Keanggotaan Variabel Beasiswa

Gambar 4. mengambarkan posisi titik data pada derajat keanggotaan. Fungsi keanggotaan dari himpunan fuzzy untuk variabel beasiswa disajikan pada Persamaan (13)-(15):

$$
\begin{aligned}
& \mu_{\text {rendah }}[\mathrm{x}]:\left\{\begin{array}{lr}
(2,5-\mathrm{x}) 1,5 ; & 0 \leq \mathrm{x} \leq 2,5 \\
0 ; & \mathrm{x} \geq 2,5
\end{array}\right. \\
& \mu_{\text {sedang }}[\mathrm{x}]:\left\{\begin{array}{lr}
0 ; & \mathrm{x} \leq 1,5 \text { atau } \mathrm{x} \geq 4 \\
(\mathrm{x}-1,5) 2 ; & 1,5 \leq \mathrm{x} \leq 3,5 \\
(4-\mathrm{x}) 0,5 ; & 3,5 \leq \mathrm{x} \leq 4
\end{array}\right.
\end{aligned}
$$


Munawaroh, Normalisa, Alvino Octaviano.

Analisa dan Penerapan Fuzzy Inference System Metode Mamdani untuk Penentuan Penerima Beasiswa.

International Journal of Artificial Intelligence, vol. 6, no. 1, pp. 21-52, June 2019. DOI: 10.36079/lamintang.ijai-0601.31

$\mu_{\text {tinggi }}[\mathrm{x}]:\left\{\begin{array}{l}0 ; \\ (\mathrm{x}-3,5) 1,5 ; \\ 1 ;\end{array}\right.$

$\mathrm{x} \Omega 3,5$

$3,5.565$

3.2. Eksperimental

Eksperimen yang dilakukan yaitu dengan data primer yang diambil selama satu semester, seperti yang ditabulasikan pada Tabel 3.

Tabel 3. Data Siswa

\begin{tabular}{|c|c|c|c|c|}
\hline SISWA & $\begin{array}{c}\text { RATA-RATA NILAI } \\
\text { RAPOR }\end{array}$ & $\begin{array}{l}\text { PENDAPATAN } \\
\text { ORANG TUA }\end{array}$ & $\begin{array}{l}\text { TANGGUNGAN } \\
\text { ORANG TUA }\end{array}$ & BEASISWA \\
\hline 1 & 74,17 & Rp1.000.000 & 3 & $?$ \\
\hline 2 & 72,96 & Rp1.290.000 & 2 & $?$ \\
\hline 3 & 72,87 & Rp1.400.000 & 5 & $?$ \\
\hline 4 & 76,96 & Rp2.000.000 & 4 & $?$ \\
\hline 5 & 73,78 & Rp1.100.000 & 4 & $?$ \\
\hline 6 & 76,7 & Rp1.750.000 & 2 & $?$ \\
\hline 7 & 75,09 & Rp1.250.000 & 5 & $?$ \\
\hline 8 & 75,13 & Rp2.200.000 & 6 & $?$ \\
\hline 9 & 72,75 & Rp3.000.000 & 3 & $?$ \\
\hline 10 & 71,3 & Rp1.500.000 & 2 & $?$ \\
\hline 11 & 72,78 & Rp1.000.000 & 3 & $?$ \\
\hline 12 & 71,57 & Rp900.000 & 4 & $?$ \\
\hline 13 & 75,22 & Rp1.850.000 & 4 & $?$ \\
\hline 14 & 70,22 & Rp2.900.000 & 3 & $?$ \\
\hline 15 & 74,3 & Rp2.500.000 & 2 & $?$ \\
\hline 16 & 75,22 & Rp800.000 & 2 & $?$ \\
\hline 17 & 76,48 & Rp1.500.000 & 3 & $?$ \\
\hline 18 & 78,3 & Rp1.100.000 & 3 & $?$ \\
\hline 19 & 75,09 & Rp2.000.000 & 4 & $?$ \\
\hline 20 & 80,52 & Rp1.500.000 & 2 & $?$ \\
\hline 21 & 78,3 & Rp1.800.000 & 4 & $?$ \\
\hline 22 & 78,22 & Rp1.450.000 & 4 & $?$ \\
\hline 23 & 78,3 & Rp800.000 & 3 & $?$ \\
\hline 24 & 78,04 & Rp925.000 & 3 & $?$ \\
\hline 25 & 77,43 & Rp1.800.000 & 4 & $?$ \\
\hline 26 & 78,96 & Rp1.300.000 & 2 & $?$ \\
\hline 27 & 77,48 & Rp1.700.000 & 3 & $?$ \\
\hline
\end{tabular}


Munawaroh, Normalisa, Alvino Octaviano.

Analisa dan Penerapan Fuzzy Inference System Metode Mamdani untuk Penentuan Penerima Beasiswa.

International Journal of Artificial Intelligence, vol. 6, no. 1, pp. 21-52, June 2019. DOI: 10.36079/lamintang.ijai-0601.31

\subsection{Evaluasi dan Validasi}

Evaluasi dan validasi hasil yang dimaksud pada penelitian ini adalah proses perhitungan nilai output fuzzy inference system metode Mamdani yang dilakukan dengan menentukan rule yang akan digunakan. Penggunaan rule disajikan pada Tabel 4.

Tabel 4. Rule Fuzzy Inference System

\begin{tabular}{|c|c|c|c|c|}
\hline \multirow[b]{2}{*}{ RULES } & \multicolumn{3}{|c|}{ INPUT } & \multirow[b]{2}{*}{ OUTPUT } \\
\hline & $\begin{array}{l}\text { RATA-RATA NILAI } \\
\text { RAPOR }\end{array}$ & PENDAPATAN & $\begin{array}{l}\text { TANGGUNGAN } \\
\text { ORANG TUA }\end{array}$ & \\
\hline 1 & Rendah & Rendah & Sedikit & Rendah \\
\hline 2 & Rendah & Rendah & Sedang & Rendah \\
\hline 3 & Rendah & Rendah & Banyak & Rendah \\
\hline 4 & Rendah & Sedang & Sedikit & Rendah \\
\hline 5 & Rendah & Sedang & Sedang & Rendah \\
\hline 6 & Rendah & Sedang & Banyak & Rendah \\
\hline 7 & Rendah & Tinggi & Sedikit & Rendah \\
\hline 8 & Rendah & Tinggi & Sedang & Rendah \\
\hline 9 & Rendah & Tinggi & Banyak & Rendah \\
\hline 10 & Sedang & Rendah & Sedikit & Sedang \\
\hline 11 & Sedang & Rendah & Sedang & Sedang \\
\hline 12 & Sedang & Rendah & Banyak & Sedang \\
\hline 13 & Sedang & Sedang & Sedikit & Sedang \\
\hline 14 & Sedang & Sedang & Sedang & Sedang \\
\hline 15 & Sedang & Sedang & Banyak & Sedang \\
\hline 16 & Sedang & Tinggi & Sedikit & Sedang \\
\hline 17 & Sedang & Tinggi & Sedang & Sedang \\
\hline 18 & Sedang & Tinggi & Banyak & Sedang \\
\hline 19 & Tinggi & Rendah & Sedikit & Tinggi \\
\hline 20 & Tinggi & Rendah & Sedang & Tinggi \\
\hline 21 & Tinggi & Rendah & Banyak & Tinggi \\
\hline 22 & Tinggi & Sedang & Sedikit & Tinggi \\
\hline 23 & Tinggi & Sedang & Sedang & Tinggi \\
\hline 24 & Tinggi & Sedang & Banyak & Tinggi \\
\hline 25 & Tinggi & Tinggi & Sedikit & Tinggi \\
\hline 26 & Tinggi & Tinggi & Sedang & Tinggi \\
\hline 27 & Tinggi & Tinggi & Banyak & Tinggi \\
\hline
\end{tabular}

\section{Hasil dan Pembahasan}

Pada penelitian ini dibahas penentuan penerima beasiswa di SMAN 1 Parung. Penentuan penerima beasiswa di SMAN 1 Parung hanya menggunakan rata-rata nilai rapor tanpa menggunakan aspek lain. Hal tersebut dapat dikatakan kurang adil jika hanya menggunakan nilai rapor sebagai tolak ukur untuk 
Munawaroh, Normalisa, Alvino Octaviano.

Analisa dan Penerapan Fuzzy Inference System Metode Mamdani untuk Penentuan Penerima Beasiswa.

International Journal of Artificial Intelligence, vol. 6, no. 1, pp. 21-52, June 2019. DOI: 10.36079/lamintang.ijai-0601.31

menerima beasiswa. Oleh karena itu, penulis mencoba menggabungkan beberapa aspek, seperti pendapatan orang tua perbulan dan jumlah tanggungan orang tua.

Penelitian ini menggunakan empat variabel, yaitu tiga variabel input yang terdiri dari variabel rata-rata nilai rapor, variabel pendapatan orang tua, dan variabel jumlah tanggungan orang tua, sedangkan untuk variabel output terdapat 1 variabel yaitu beasiswa. Aturan yang dapat terbentuk dapat disajikan pada Tabel 5.

Tabel 5. Hasil Aturan-Aturan yang Terbentuk pada Fuzzy Inference

\begin{tabular}{|c|c|c|c|c|}
\hline \multirow[b]{2}{*}{ RULES } & \multicolumn{3}{|c|}{ INPUT } & \multirow[b]{2}{*}{ OUTPUT } \\
\hline & $\begin{array}{c}\text { RATA-RATA } \\
\text { NILAI RAPOR } \\
\end{array}$ & PENDAPATAN & $\begin{array}{c}\text { TANGGUNGAN } \\
\text { ORANG TUA }\end{array}$ & \\
\hline 1 & Rendah & Rendah & Sedikit & Rendah \\
\hline 2 & Rendah & Rendah & Sedang & Rendah \\
\hline 3 & Rendah & Rendah & Banyak & Rendah \\
\hline 4 & Rendah & Sedang & Sedikit & Rendah \\
\hline 5 & Rendah & Sedang & Sedang & Rendah \\
\hline 6 & Rendah & Sedang & Banyak & Rendah \\
\hline 7 & Rendah & Tinggi & Sedikit & Rendah \\
\hline 8 & Rendah & Tinggi & Sedang & Rendah \\
\hline 9 & Rendah & Tinggi & Banyak & Rendah \\
\hline 10 & Sedang & Rendah & Sedikit & Sedang \\
\hline 11 & Sedang & Rendah & Sedang & Sedang \\
\hline 12 & Sedang & Rendah & Banyak & Sedang \\
\hline 13 & Sedang & Sedang & Sedikit & Sedang \\
\hline 14 & Sedang & Sedang & Sedang & Sedang \\
\hline 15 & Sedang & Sedang & Banyak & Sedang \\
\hline 16 & Sedang & Tinggi & Sedikit & Sedang \\
\hline 17 & Sedang & Tinggi & Sedang & Sedang \\
\hline 18 & Sedang & Tinggi & Banyak & Sedang \\
\hline 19 & Tinggi & Rendah & Sedikit & Tinggi \\
\hline 20 & Tinggi & Rendah & Sedang & Tinggi \\
\hline 21 & Tinggi & Rendah & Banyak & Tinggi \\
\hline 22 & Tinggi & Sedang & Sedikit & Tinggi \\
\hline 23 & Tinggi & Sedang & Sedang & Tinggi \\
\hline 24 & Tinggi & Sedang & Banyak & Tinggi \\
\hline 25 & Tinggi & Tinggi & Sedikit & Tinggi \\
\hline 26 & Tinggi & Tinggi & Sedang & Tinggi \\
\hline 27 & Tinggi & Tinggi & Banyak & Tinggi \\
\hline
\end{tabular}

Berdasarkan Tabel 5, aturan yang terbentuk pada interferensi Fuzzy meliputi: 
R1 : If (Rata-rata nilai rapor is rendah) And (Pendapatan is rendah) And (Tanggungan Orang tua is Sedikit) Then (beasiswa is rendah)

R2 : If (Rata-rata nilai rapor is rendah) And (Pendapatan is rendah) And (Tanggungan Orang tua is sedang) Then (beasiswa is rendah)

R3 : If (Rata-rata nilai rapor is rendah) And (Pendapatan is rendah) And (Tanggungan Orang tua Banyak) Then (beasiswa is rendah)

R4 : If (Rata-rata nilai rapor is rendah) And (Pendapatan is Sedang) And (Tanggungan Orang tua is Sedikit) Then (beasiswa is rendah)

R5 : If (Rata-rata nilai rapor is rendah) And (Pendapatan is Sedang) And (Tanggungan Orang tua is sedang) Then (beasiswa is rendah)

R6 : If (Rata-rata nilai rapor is rendah) And (Pendapatan is Sedang) And (Tanggungan Orang tua Banyak) Then (beasiswa is rendah)

R7 : If (Rata-rata nilai rapor is rendah) And (Pendapatan is tinggi) And (Tanggungan Orang tua is Sedikit) Then (beasiswa is rendah)

R8 : If (Rata-rata nilai rapor is rendah) And (Pendapatan is tinggi) And (Tanggungan Orang tua is sedang) Then (beasiswa is rendah)

R9 : If (Rata-rata nilai rapor is rendah) And (Pendapatan is tinggu) And (Tanggungan Orang tua Banyak) Then (beasiswa is rendah)

R10 : If (Rata-rata nilai rapor is sedang) And (Pendapatan is rendah) And (Tanggungan Orang tua is Sedikit) Then (beasiswa is sedang)

R11 : If (Rata-rata nilai rapor is sedang) And (Pendapatan is rendah) And (Tanggungan Orang tua is sedang) Then (beasiswa is sedang)

R12 : If (Rata-rata nilai rapor is sedang) And (Pendapatan is rendah) And (Tanggungan Orang tua Banyak) Then (beasiswa is sedang)

R13 : If (Rata-rata nilai rapor is sedang) And (Pendapatan is Sedang) And (Tanggungan Orang tua is Sedikit) Then (beasiswa is sedang)

R14 : If (Rata-rata nilai rapor is sedang) And (Pendapatan is Sedang) And (Tanggungan Orang tua is sedang) Then (beasiswa is sedang)

R15 : If (Rata-rata nilai rapor is sedang) And (Pendapatan is Sedang) And (Tanggungan Orang tua Banyak) Then (beasiswa is sedang)

R16 : If (Rata-rata nilai rapor is sedang) And (Pendapatan is tinggi) And (Tanggungan Orang tua is Sedikit) Then (beasiswa is sedang)

R17 : If (Rata-rata nilai rapor is sedang) And (Pendapatan is tinggi) And (Tanggungan Orang tua is sedang) Then (beasiswa is sedang)

R18 : If (Rata-rata nilai rapor is sedang) And (Pendapatan is tinggi) And (Tanggungan Orang tua Banyak) Then (beasiswa is sedang)

R19 : If (Rata-rata nilai rapor is tinggi) And (Pendapatan is rendah) And (Tanggungan Orang tua is Sedikit) Then (beasiswa is tinggi)

R20 : If (Rata-rata nilai rapor is tinggi) And (Pendapatan is rendah) And (Tanggungan Orang tua is sedang) Then (beasiswa is tinggi)

R21 : If (Rata-rata nilai rapor is tinggi) And (Pendapatan is rendah) And (Tanggungan Orang tua Banyak) Then (beasiswa is tinggi)

R22 : If (Rata-rata nilai rapor is tinggi) And (Pendapatan is Sedang) And (Tanggungan Orang tua is Sedikit) Then (beasiswa is tinggi)

R23 : If (Rata-rata nilai rapor is tinggi) And (Pendapatan is Sedang) And (Tanggungan Orang tua is sedang) Then (beasiswa is tinggi)

R24 : If (Rata-rata nilai rapor is tinggi) And (Pendapatan is Sedang) And (Tanggungan Orang tua Banyak) Then (beasiswa is tinggi)

R25 : If (Rata-rata nilai rapor is tinggi) And (Pendapatan is tinggi) And (Tanggungan Orang tua is Sedikit) Then (beasiswa is tinggi)

R26 : If (Rata-rata nilai rapor is tinggi) And (Pendapatan is tinggi) And (Tanggungan Orang tua is sedang) Then (beasiswa is tinggi)

R27 : If (Rata-rata nilai rapor is tinggi) And (Pendapatan is tinggi) And (Tanggungan Orang tua Banyak) Then (beasiswa is tinggi) 


\subsection{Penyelesaian Masalah Menggunakan Metode Mamdani}

Penyelesaian masalah untuk kasus penentuan penerima beasiswa menggunakan metode Mamdani terdiri atas proses fuzzifikasi, implikasi, komposisi aturan, defuzzifikasi.

\subsubsection{Proses Fuzzifikasi}

Pada tahap fuzzifikasi, akan dihitung nilai derajat keanggotaan untuk semua data. Sebagai contoh diambil dari data pertama dengan siswa nomor 1 yang mempunyai nilai rata-rata rapor 74,17 pendapatan orang tua 1 juta dan jumlah tanggungan orang tua 3 . Tahapan fuzzifikasi terdiri dari empat tahapan sebagai berikut:

1. Menghitung derajat keanggotaan rata-rata nilai rapor sesuai dengan Persamaan (16)-(17):

$$
\begin{array}{rlr}
\left.\mu_{\text {rendah }} \mathrm{x}\right]: & \left\{\begin{array}{lr}
(77-\mathrm{x}) / 7 ; & 0 \leq \mathrm{x} \leq 77 \\
0 ; & \mathrm{x} \geq 77
\end{array}\right. \\
& =(77-74,17) / 7=0,4 \\
\mu_{\text {sedang }}[\mathrm{x}]: & \mathrm{x} \leq 73 \text { atau } \mathrm{x} \geq 80 \\
0 ; & 73 \leq \mathrm{x} \leq 77 \\
(\mathrm{x}-73) / 4 ; & 77 \leq \mathrm{x} \leq 80 \\
(80-\mathrm{x}) 3 ; &
\end{array}
$$

Derajat keanggotaan nilai rata-rata rapor siswa nomor 1 disajikan pada Gambar 5.

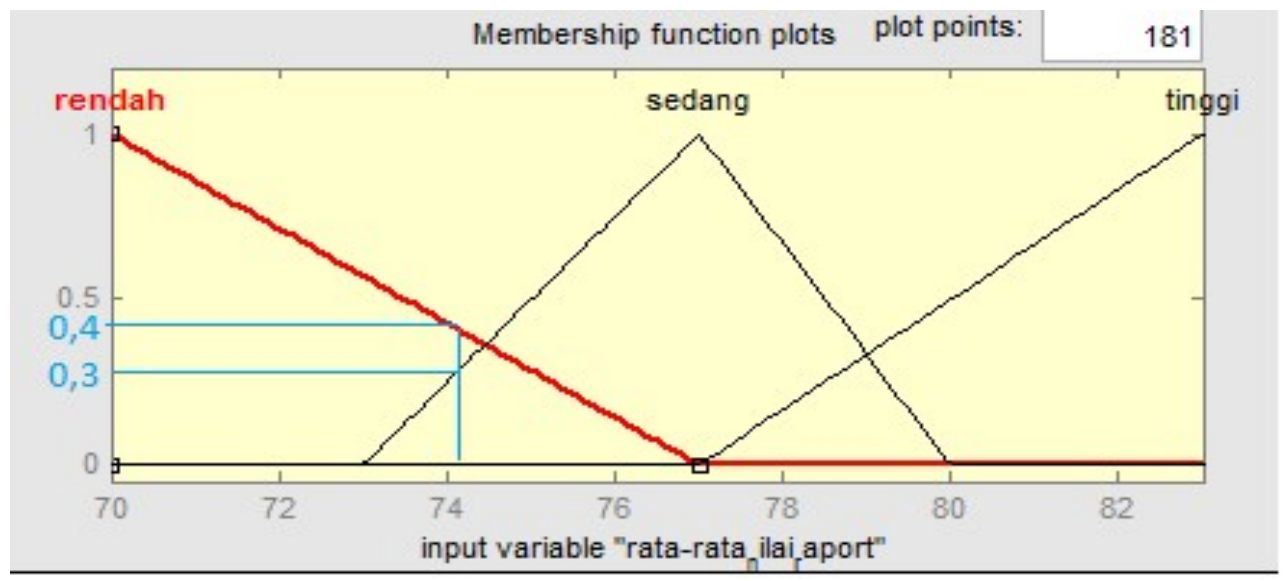

Gambar 5. Fungsi Keanggotaan Variabel Input Rata-Rata Nilai rapor 74,17

2. Menghitung derajat keanggotaan pendapatan sesuai dengan Persamaan (18)-(19):

$$
\begin{aligned}
& \mu_{\text {tinggi }}[\mathrm{x}]:\left\{\begin{array}{lr}
(1,5 \text { juta-x }) / 1,5 j u t 3: & 0 \leq \mathrm{x} \leqslant 1,5 \text { juta } \\
0 ; & \mathrm{x} \geq 1,5 \text { juta }
\end{array}\right. \\
& =(1,5 \text { juta }-1 \text { juta }) / 1,5 \text { juta }=0,3 \\
& \mu_{\text {sedang }}[x]:\left\{\begin{array}{lr}
0 ; & x \leq 0,5 \text { juta atau } x \geq 2,5 \text { juta } \\
(\mathrm{x}-0.5 \text { juta } / 1 \text { juta: } & 0.5 \text { juta }<\mathrm{x}<1.5 \text { juta } \\
(2 \text { juta- } \mathrm{x}) 0,75 \mathrm{juta} ; & 1,5 \mathrm{juta} \leq \mathrm{x} \leq 2,5 \text { juta }
\end{array}\right. \\
& =(1 \text { juta- } 0,5 \text { juta }) / 1 \text { juta }=0,5 \text { juta } / 1 \text { juta }=0,5
\end{aligned}
$$


Derajat keanggotaan pendapatan siswa nomor 1 disajikan pada Gambar 6.

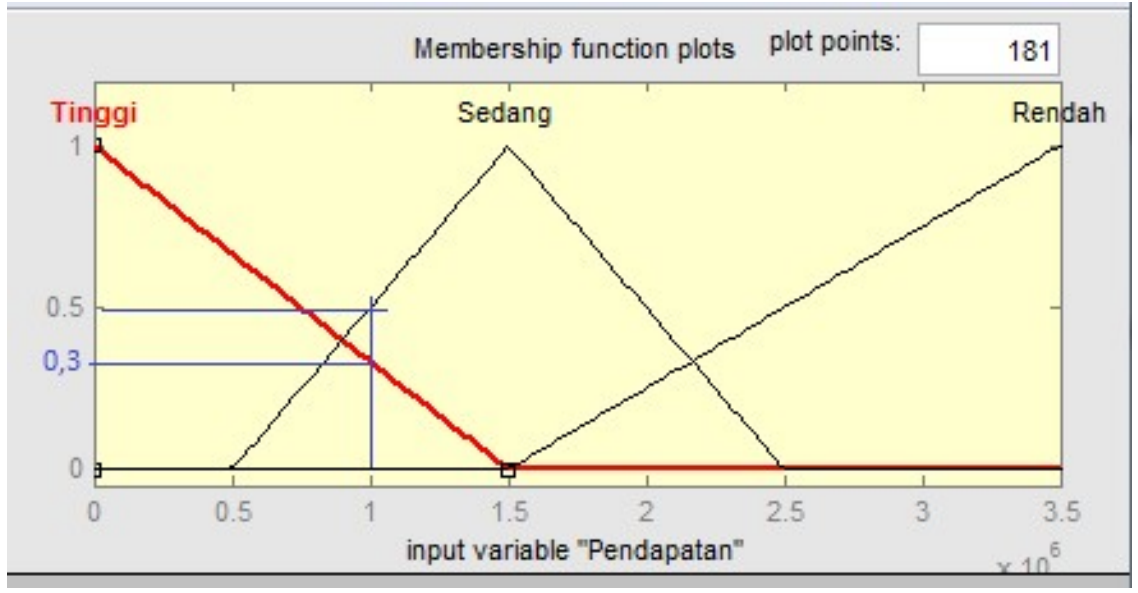

Gambar 6. Fungsi Keanggotan Variabel Input Pendapatan Orang tua

3. Menghitung derajat keanggotaan tanggungan orang tua sesuai dengan Persamaan (20)-(21):

$$
\begin{gathered}
\mu_{\text {sedikit }}[\mathrm{x}]:\left\{\begin{array}{rr}
(3-\mathrm{x}) / 3 ; & 0 \leq \mathrm{x} \leq 3 \\
0 ; & \mathrm{x} \geq 3
\end{array}\right. \\
\mu_{\text {sedang }}[\mathrm{x}]:\left\{\begin{array}{rr}
0 ; & \text { karena } \mathrm{x}=3 \\
(\mathrm{x}-2) / 1 ; & \mathrm{x} \leq 2 \text { atalı } \mathrm{x} \geq 4 \\
(4-\mathrm{x}) 1 ; & 2 \leq \mathrm{x} \leq 3 \\
=(3-2) / 1=1 & 3 \leq \mathrm{x} \leq 4
\end{array}\right.
\end{gathered}
$$

Derajat keanggotaan tanggungan orang tua siswa 1 disajikan pada Gambar 7.

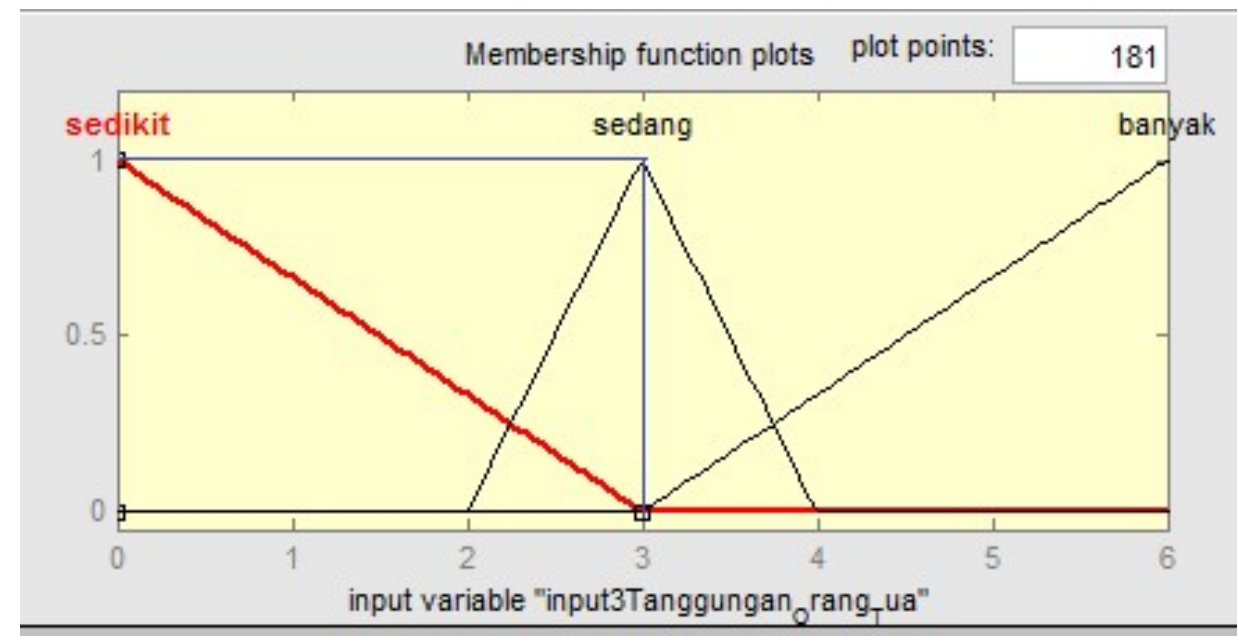

Gambar 7. Fungsi Keanggotaan Variabel Input Jumlah Tanggungan Orang Tua 
4. Menghitung derajat keanggotaan variabel sesuai dengan Persamaan (22)-(23):

$$
\mu_{\text {rendah }}[\mathrm{x}]:\left\{\begin{array}{lr}
(2,5-\mathrm{x}) / 1,5 ; & 1 \leq \mathrm{x} \leq 2,5 \\
0 ; & \mathrm{x} \geq 2,5
\end{array}\right.
$$

a. $(2,5-\mathrm{x}) / 1,5=0,4 ; \mathrm{X}=2,5-0,6=1,9$

b. $(2,5-\mathrm{x}) / 1,5=0,3 ; X=2,5-0,45=2,05$

$$
\begin{array}{r}
\mu_{\text {sedang }}[\mathrm{x}]:\left\{\begin{array}{rr}
0 ; & \mathrm{x} \leq 1,5 \text { atau } \mathrm{x} \geq 4 \\
(\mathrm{x}-1.5) / 2 ; & 1,5<\mathrm{x}<3.5 \\
(4-\mathrm{x}) / 0,5 ; & 3,5 \leq \mathrm{x} \leq 4
\end{array}\right. \\
\text { c. }(\mathrm{x}-1,5) / 2=0,4 ; \mathrm{X}=0,8+1,5=2,3 \\
\text { d. }(\mathrm{x}-1,5) / 2=0,3 ; \mathrm{X}=0,6+1,5=2,1 \\
\text { e. }(4-\mathrm{x}) / 0,5=0,4 ; \mathrm{X}=4-0,2=3,8 \\
\text { f. }(4-\mathrm{x}) / 0,5=0,3 ; \mathrm{X}=4-0,15=3,85
\end{array}
$$

Derajat keanggotaan nilai beasiswa siswa pertama disajikan pada Gambar 8.

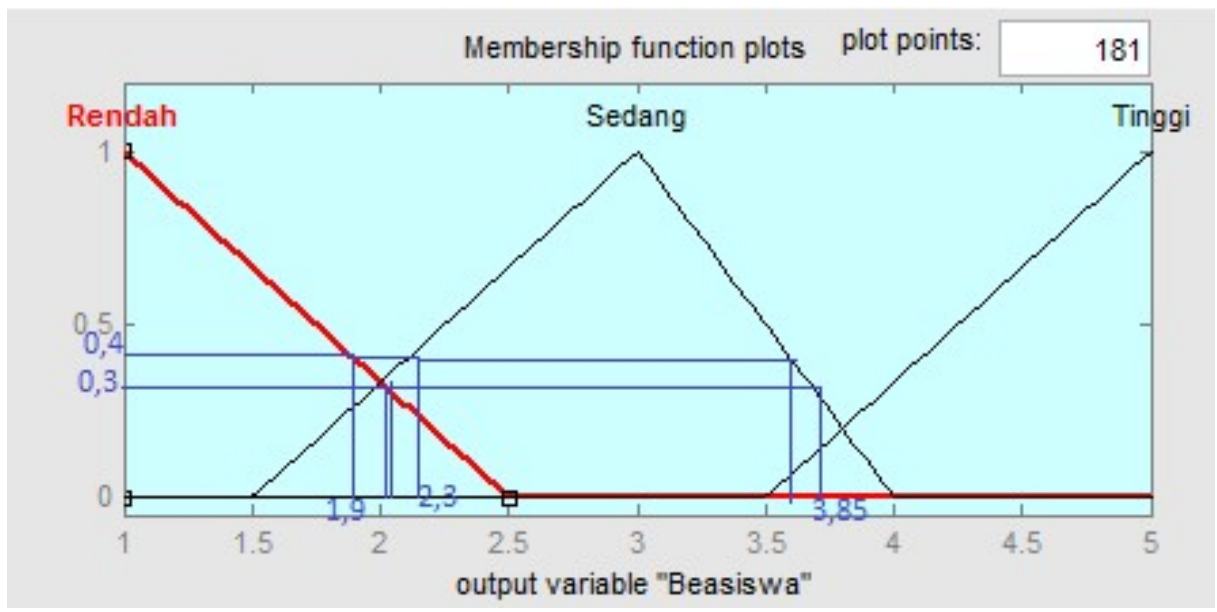

Gambar 8. Fungsi Keanggotaan Variabel Output Beasiswa Siswa Pertama

Secara keseluruhan nilai derajat keanggotaan untuk setiap data dapat dilihat pada Tabel 6, Tabel 7, dan Tabel 8. 
Tabel 6. Derajat Keanggotaan Rata-Rata Nilai Rapor

\begin{tabular}{|c|c|c|c|c|}
\hline \multirow{2}{*}{ Siswa } & \multirow{2}{*}{ Rata-Rata Nilai Rapor } & \multicolumn{3}{|c|}{ Derajat Keanggotaan } \\
\hline & & Rendah & Sedang & Tinggi \\
\hline 1 & 74,17 & 0,4 & 0,3 & - \\
\hline 2 & 72,96 & 0,58 & - & - \\
\hline 3 & 72,87 & 0,59 & - & - \\
\hline 4 & 76,96 & 0,01 & 0,97 & - \\
\hline 5 & 73,78 & 0,46 & 0,2 & - \\
\hline 6 & 76,7 & 0,042 & 0,92 & - \\
\hline 7 & 75,09 & 0,3 & 0,52 & \\
\hline 8 & 75,13 & 0,27 & 0,5 & \\
\hline 9 & 72,75 & 0,6 & - & - \\
\hline 10 & 71,3 & 0,8 & - & - \\
\hline 11 & 72,78 & 0,6 & - & - \\
\hline 12 & 71,57 & 0,7 & - & - \\
\hline 13 & 75,22 & 0,25 & 0,5 & - \\
\hline 14 & 70,22 & 0,9 & - & - \\
\hline 15 & 74,3 & 0,38 & 0,5 & - \\
\hline 16 & 75,22 & 0,25 & 0,5 & - \\
\hline 17 & 76,48 & 0,52 & 0,87 & - \\
\hline 18 & 78,3 & - & 0,56 & 0,2 \\
\hline 19 & 75,09 & 0,27 & 0,5 & - \\
\hline 20 & 80,52 & - & - & 0,58 \\
\hline 21 & 78,3 & - & 0,56 & 0,2 \\
\hline 22 & 78,22 & - & 0,59 & 0,2 \\
\hline 23 & 78,3 & - & 0,56 & 0,2 \\
\hline 24 & 78,04 & - & 0,65 & 0,17 \\
\hline 25 & 77,43 & - & 0,85 & 0,07 \\
\hline 26 & 78,96 & - & 0,34 & 0,32 \\
\hline 27 & 77,48 & - & 0,84 & 0,08 \\
\hline
\end{tabular}


Tabel 7. Derajat Keanggotaan Pendapatan

\begin{tabular}{|c|c|c|c|c|}
\hline \multirow{2}{*}{ Siswa } & \multirow{2}{*}{ Pendapatan } & \multicolumn{3}{|c|}{ Derajat Keanggotaan } \\
\hline & & Tinggi & Sedang & Rendah \\
\hline 1 & Rp1.000.000 & 0,3 & 0,5 & - \\
\hline 2 & Rp1.290.000 & 0,14 & 0,79 & 0 \\
\hline 3 & Rp1.400.000 & 0,06 & 0,9 & 0 \\
\hline 4 & Rp2.000.000 & & 0,5 & 0,25 \\
\hline 5 & Rp1.100.000 & 0,27 & 0,6 & \\
\hline 6 & Rp1.750.000 & & 0,75 & 0,125 \\
\hline 7 & Rp1.250.000 & & 0,2 & 0,75 \\
\hline 8 & Rp2.200.000 & & & 0,35 \\
\hline 9 & Rp3.000.000 & - & - & 0,75 \\
\hline 10 & Rp1.500.000 & & 1 & \\
\hline 11 & Rp1.000.000 & 0,3 & 0,5 & - \\
\hline 12 & Rp900.000 & 0,4 & 0,4 & - \\
\hline 13 & Rp1.850.000 & - & 0,65 & 0,17 \\
\hline 14 & Rp2.900.000 & - & - & 0,7 \\
\hline 15 & Rp2.500.000 & - & - & 0,6 \\
\hline 16 & Rp600.000 & 0,6 & 0,1 & - \\
\hline 17 & Rp1.500.000 & - & 1 & \\
\hline 18 & Rp1.100.000 & 0,27 & 0,26 & \\
\hline 19 & Rp2.000.000 & - & 0,5 & 0,25 \\
\hline 20 & Rp1.500.000 & 0 & 1 & \\
\hline 21 & Rp1.800.000 & - & 0,7 & 0,15 \\
\hline 22 & Rp1.450.000 & 0,03 & 0,95 & \\
\hline 23 & Rp800.000 & 0,46 & 0,3 & - \\
\hline 24 & Rp925.000 & 0,58 & 0,42 & - \\
\hline 25 & Rp1.800.000 & - & 0,7 & 0,15 \\
\hline 26 & Rp1.300.000 & 0,13 & 0,8 & \\
\hline 27 & Rp1.700.000 & - & 0,8 & 0,1 \\
\hline
\end{tabular}


Tabel 8. Derajat Keanggotaan Jumlah Tanggungan Orang Tua

\begin{tabular}{|c|c|c|c|c|}
\hline \multirow{2}{*}{ Siswa } & \multirow{2}{*}{ Tanggungan Orang Tua } & \multicolumn{3}{|c|}{ Derajat Keanggotaan } \\
\hline & & Sedikit & Sedang & Banyak \\
\hline 1 & 3 & 0 & 1 & - \\
\hline 2 & 2 & 0,33 & 0 & - \\
\hline 3 & 5 & - & & 0,67 \\
\hline 4 & 4 & - & 0 & 0,3 \\
\hline 5 & 4 & - & 0 & 0,3 \\
\hline 6 & 2 & 0,33 & 0 & - \\
\hline 7 & 5 & - & & 0,67 \\
\hline 8 & 5 & - & - & 0,67 \\
\hline 9 & 3 & 0 & 1 & - \\
\hline 10 & 2 & 0,33 & 0 & - \\
\hline 11 & 3 & 0 & 1 & - \\
\hline 12 & 4 & - & & 0,3 \\
\hline 13 & 6 & - & 0 & 1 \\
\hline 14 & 3 & 0 & 1 & - \\
\hline 15 & 2 & 0,33 & & - \\
\hline 16 & 4 & - & & 0,3 \\
\hline 17 & 3 & 0 & 1 & - \\
\hline 18 & 4 & - & & 0,3 \\
\hline 19 & 4 & - & & 0,3 \\
\hline 20 & 2 & 0,33 & 0 & - \\
\hline 21 & 5 & - & 0 & 0,67 \\
\hline 22 & 4 & - & 0 & 0,3 \\
\hline 23 & 4 & - & 0 & 0,3 \\
\hline 24 & 3 & 0 & 1 & - \\
\hline 25 & 4 & - & 0 & 0,3 \\
\hline 26 & 2 & 0,33 & 0 & - \\
\hline 27 & 3 & 0 & 1 & - \\
\hline
\end{tabular}

\subsubsection{Proses Implikasi}

Aturan yang digunakan adalah aturan MIN pada fungsi implikasi. Proses implikasi dilakukan dengan memasangkan derajat keanggotaan dengan aturan yang digunakan. Inferensi dengan crisp input ratarata nilai rapor 74,17, dan Pendapatan Rp.1juta, dan jumlah tanggungan orang tua 3, seperti pada Tabel 9. 
Tabel 9. Inferensi dengan Crisp Input Data Siswa Pertama

\begin{tabular}{ccccc}
\hline \multirow{2}{*}{ RULES } & \multicolumn{3}{c}{ INPUT } & \multirow{2}{*}{ OUTPUT } \\
\cline { 2 - 4 } & $\begin{array}{c}\text { RATA-RATA } \\
\text { NILAI RAPOR }\end{array}$ & PENDAPATAN & $\begin{array}{c}\text { TANGGUNGAN } \\
\text { ORANG TUA }\end{array}$ & \\
\hline 4 & Rendah & Sedang & Sedikit & Rendah \\
\hline 5 & Rendah & Sedang & Sedang & Rendah \\
\hline 7 & Rendah & Tinggi & Sedikit & Rendah \\
\hline 8 & Rendah & Tinggi & Sedang & Rendah \\
\hline 13 & Sedang & Sedang & Sedikit & Sedang \\
\hline 14 & Sedang & Sedang & Sedang & Sedang \\
\hline 16 & Sedang & Tinggi & Sedikit & Sedang \\
\hline 17 & Sedang & Tinggi & Sedang & Sedang \\
\hline
\end{tabular}

Keterangan:

R4 : If (Rata-rata nilai rapor is rendah) And (Pendapatan is Sedang) And (Tanggungan Orang tua is Sedikit ) Then (beasiswa is rendah)

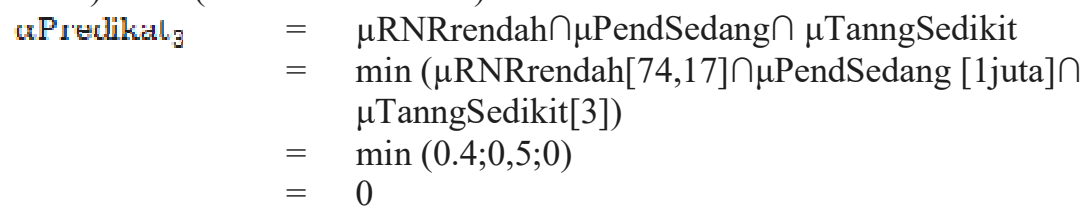

R5 : If (Rata-rata nilai rapor is rendah) And (Pendapatan is Sedang) And (Tanggungan Orang tua is sedang) Then (beasiswa is rendah)

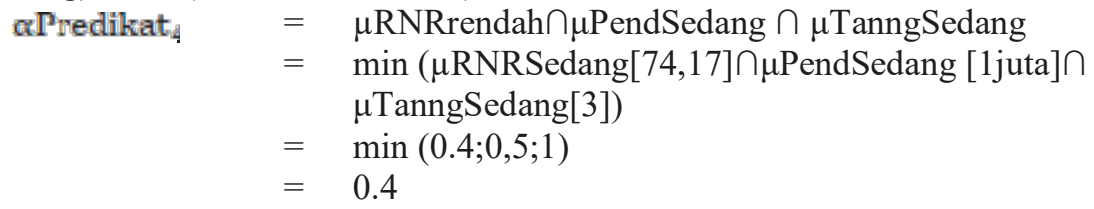

R7 : If (Rata-rata nilai rapor is rendah ) And (Pendapatan is tinggi ) And (Tanggungan Orang tua is Sedikit) Then (beasiswa is rendah)

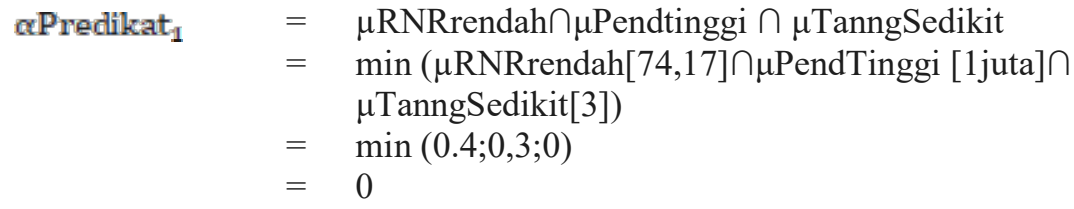

R8 : If (Rata-rata nilai rapor is rendah) And (Pendapatan is tinggi) And (Tanggungan Orang tua is sedang ) Then (beasiswa is rendah)

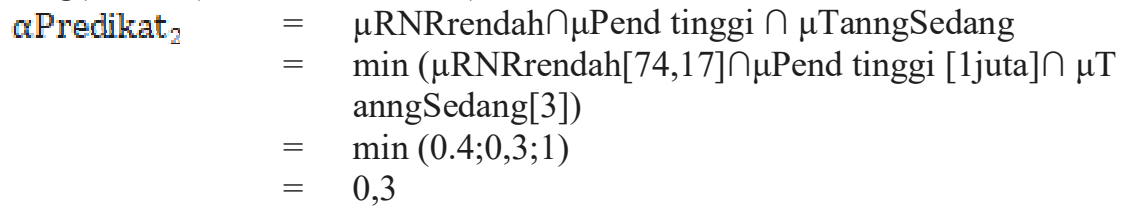


Munawaroh, Normalisa, Alvino Octaviano.

Analisa dan Penerapan Fuzzy Inference System Metode Mamdani untuk Penentuan Penerima Beasiswa.

R13 : If (Rata-rata nilai rapor is sedang) And (Pendapatan is Sedang) And (Tanggungan Orang tua is Sedikit) Then (beasiswa is sedang)

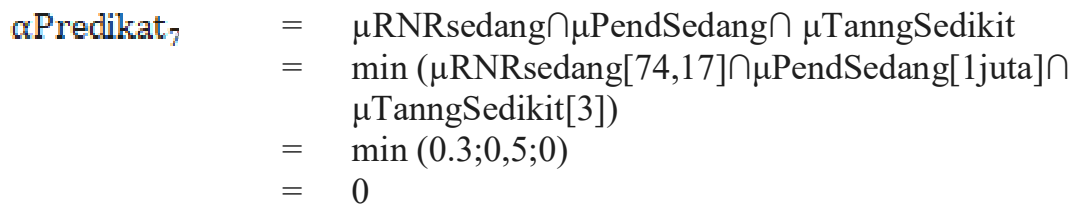

R14 : If (Rata-rata nilai rapor is sedang) And (Pendapatan is Sedang) And (Tanggungan Orang tua is sedang ) Then (beasiswa is sedang)

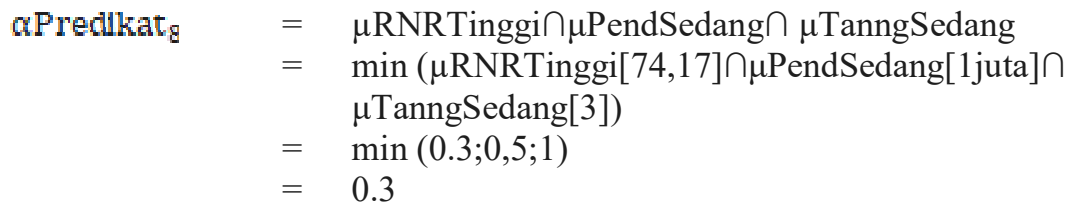

R16 : If (Rata-rata nilai rapor is sedang) And (Pendapatan is tinggi) And (Tanggungan Orang tua is Sedikit) Then (beasiswa is sedang)

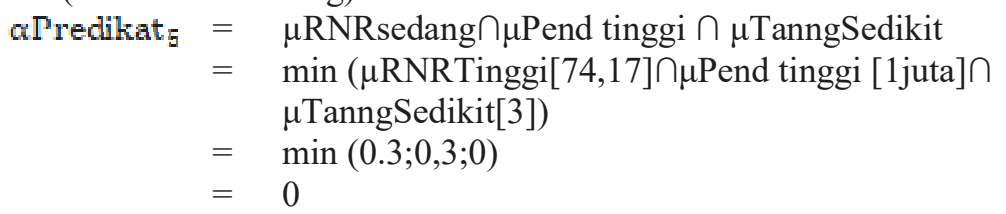

R17 : If (Rata-rata nilai rapor is sedang) And (Pendapatan is tinggi) And (Tanggungan Orang tua is sedang ) Then (beasiswa is sedang)

$$
\begin{aligned}
\boldsymbol{\alpha P r o d i k a t}_{\tilde{\mathbf{c}}} & =\mu \mathrm{RNR} \text { Redang } \cap \mu \text { Pend tinggi } \cap \mu \text { TanngSedang } \\
& =\min (\mu \mathrm{RNRTinggi}[74,17] \cap \mu \text { Pend tinggi }[1 \text { juta }] \cap \\
& \mu \text { TanngSedang[3]) } \\
& =0,3
\end{aligned}
$$

\subsubsection{Komposisi Antar Aturan}

Aplikasi fungsi stiap aturan menggunakan metode MAX untuk melakukan komposisi antar semua aturan. Setelah komposisi antar semua aturan dilakukan, maka akan didapat output melalui langkah defuzzifikasi seperti pada Gambar 9.

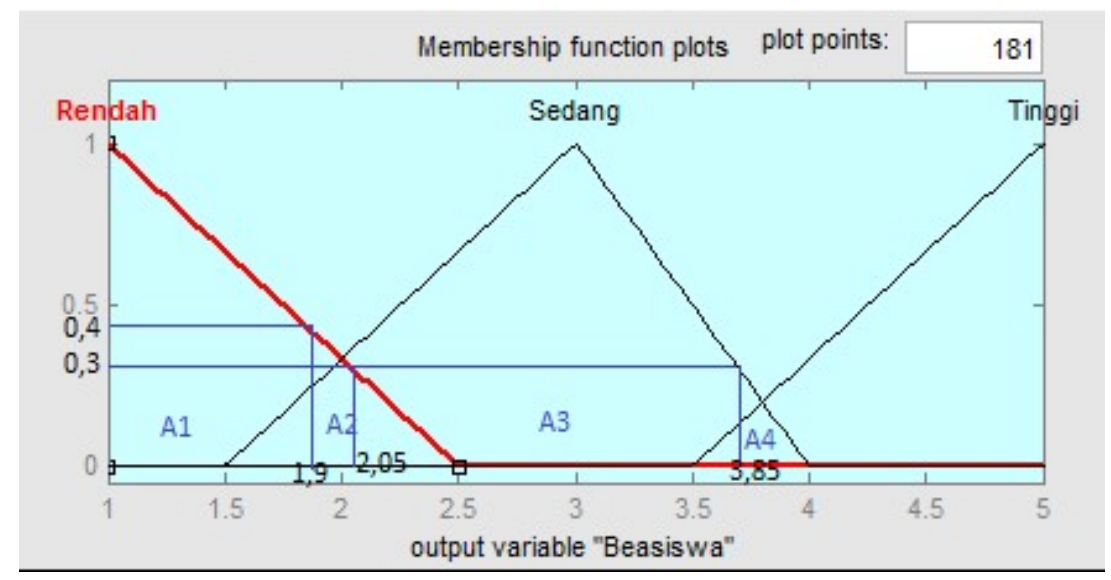

Gambar 9. Daerah Fuzzy 
Munawaroh, Normalisa, Alvino Octaviano.

Analisa dan Penerapan Fuzzy Inference System Metode Mamdani untuk Penentuan Penerima Beasiswa.

International Journal of Artificial Intelligence, vol. 6, no. 1, pp. 21-52, June 2019. DOI: 10.36079/lamintang.ijai-0601.31

\subsubsection{Defuzzifikasi}

Proses defuzzifikasi untuk fuzzy inference system metode Mamdani dilakukan dengan 2 tahap meliputi:

1. Defuzzifikasi dilakukan dengan menggunakan metode centroid dengan Persamaan (24):

$$
\begin{aligned}
& \mathrm{Z}=\frac{\mathrm{M} 1+\mathrm{M} \mathrm{Q}+\mathrm{MB}+\mathrm{M} 4}{\mathrm{~A} 1+\mathrm{A} 2+\mathrm{A} 3+\mathrm{A} 4} \\
& \mathrm{M} 1=\int_{1}^{1, y} 0,4=0,\left.2 \mathrm{x}^{2}\right|_{1} ^{1, y}=\left[\left(0,2^{*}\left(1,9^{2}\right)\right)-\left(0,2^{*}\left(1^{2}\right)\right)\right] \\
& =0,722-0,2=0,522 \\
& \text { A1 }=(1,9-1) * 0,4=0,9 * 0,4=0,36 \\
& \mathrm{M} 2=\int_{1,9}^{2, \omega} \frac{2,5-1}{1,5}=1,6 \mathrm{x}-0,6 \mathrm{x}^{2}=0,8 \mathrm{x}^{2}-0,2 \mathrm{x}^{3} \\
& =\left[\left(-0,2\left(2,05^{3}\right)+0,8\left(2,05^{2}\right)\right]-\left[\left(-0,2\left(1,9^{3}\right)+0,8\left(1,9^{2}\right)\right]\right.\right. \\
& =(-1,72+3,362)-(-1,37+2,89 \\
& =1,64-1,52=0,12 \\
& \mathrm{~A} 2=(0,4+0,3) *(2,05-1,9) / 2=0,0525 \\
& \mathrm{M} 3=\int_{2,05}^{3,85} 0,3=0,\left.15 \mathrm{x}^{2}\right|_{2,05} ^{3, \mathrm{x} 2}=\left[\left(0,15^{*}\left(3,85^{2}\right)\right)-\left(0,15 *\left(2,05^{2}\right)\right)\right] \\
& =2,22-0,63=1,59 \\
& \text { A3 }=0,3 *(3,85-2,05)=0,54 \\
& \begin{aligned}
\mathrm{M} 4 & =\int_{3,85 \frac{4-x}{0,5}}^{4}=8 \mathrm{x}-2 \mathrm{x}^{2}=4 \mathrm{x}^{2}-0,67 \mathrm{x}^{3} \\
& =\left[\left(-0,67\left(4^{3}\right)+4\left(4^{2}\right)\right]-\left[\left(-0,67\left(3,85^{3}\right)+4\left(3,85^{2}\right)\right]\right.\right. \\
& =(-42,8+64)-(-38,2+59,29 \\
& =21,12-21,09=0,03
\end{aligned} \\
& \text { A4 }=(4-3,85) * 0,3 / 2=0,0225 \\
& Z=\frac{0,522+0,12+1,59+0,03}{0,36+0,053+0,54+0,022:}=\frac{2,26}{0,9755}=2,31
\end{aligned}
$$

2. Defuzzifikasi Menggunakan Matlab

Defuzzifikasi dilakukan dengan crisp input rata-rata nilai rapor 74,17, pendapatan Rp.1juta, dan tanggungan orang tua sebanyak 3 orang. Hasil simulasi metode Mamdani menunjunkan bahwa rata-rata nilai rapor 74,17 , pendapatan Rp.1juta, dan tanggungan orang tua sebanyak 3 orang maka peluang siswa tersebut untuk mendapatkan beasiswa tersebut sebanyak 2,31.

Penelitian ini menggunakan metode fuzzy Mamdani dengan defuzzifikasi metode centroid. Hal ini dapat dilihat pada Gambar 10. 


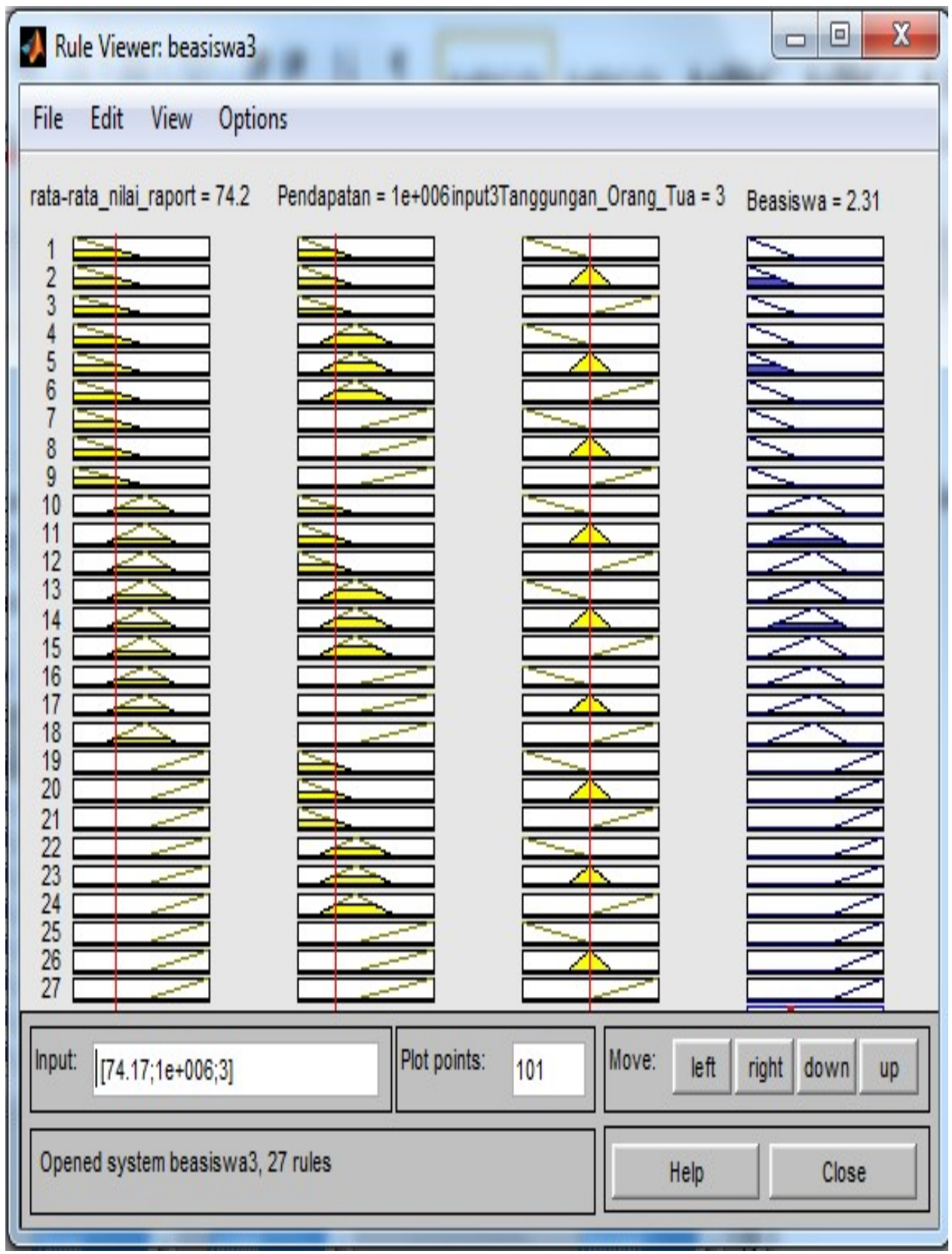

Gambar 10. Tampilan Komposisi Aturan

Berdasarkan hasil defuzzifikasi menggunakan metode centroid yang telah didapatkan pada calon penerima beasiswa SMAN 1 Parung dapat dilihat pada Tabel 10. 
Tabel 10. Hasil Perhitungan dengan Metode Centroid

\begin{tabular}{|c|c|c|c|c|c|}
\hline \multirow[b]{2}{*}{$\begin{array}{l}\text { NAMA } \\
\text { SISWA }\end{array}$} & \multicolumn{3}{|c|}{ VARIABEL INPUT } & \multirow[b]{2}{*}{$\begin{array}{c}\text { NILAI Z } \\
\text { MAMDANI }\end{array}$} & \multirow[b]{2}{*}{ HASIL } \\
\hline & $\begin{array}{c}\text { RATA-RATA } \\
\text { NILAI } \\
\text { RAPOR } \\
\end{array}$ & PENDAPATAN & $\begin{array}{l}\text { TANGGUNGAN } \\
\text { ORANG TUA }\end{array}$ & & \\
\hline 1 & 74,17 & Rp1.000.000 & 3 & 2,31 & Rendah \\
\hline 2 & 72,96 & Rp1.290.000 & 2 & 1,62 & Rendah \\
\hline 3 & 72,87 & Rp1.400.000 & 5 & 1,55 & Rendah \\
\hline 4 & 76,96 & Rp2.000.000 & 4 & 2,78 & Sedang \\
\hline 5 & 73,78 & Rp1.100.000 & 4 & 2,25 & Rendah \\
\hline 6 & 76,7 & Rp1.750.000 & 2 & 2,74 & Sedang \\
\hline 7 & 75,09 & Rp1.250.000 & 5 & 2,56 & Sedang \\
\hline 8 & 75,13 & Rp2.200.000 & 6 & 2,49 & Rendah \\
\hline 9 & 72,75 & Rp3.000.000 & 3 & 1,54 & Rendah \\
\hline 10 & 71,3 & Rp1.500.000 & 2 & 1,62 & Rendah \\
\hline 11 & 72,78 & Rp1.000.000 & 3 & 1,57 & Rendah \\
\hline 12 & 71,57 & Rp900.000 & 4 & 1,62 & Rendah \\
\hline 13 & 75,22 & Rp1.850.000 & 6 & 2,49 & Rendah \\
\hline 14 & 70,22 & Rp2.900.000 & 3 & 1,52 & Rendah \\
\hline 15 & 74,3 & Rp2.500.000 & 2 & 2,4 & Rendah \\
\hline 16 & 75,22 & Rp800.000 & 2 & 2,49 & Rendah \\
\hline 17 & 76,48 & Rp1.500.000 & 3 & 2,78 & Sedang \\
\hline 18 & 78,3 & Rp1.100.000 & 3 & 3,13 & Sedang \\
\hline 19 & 75,09 & Rp2.000.000 & 4 & 2,47 & Rendah \\
\hline 20 & 80,52 & Rp1.500.000 & 2 & 4,38 & Tinggi \\
\hline 21 & 78,3 & Rp1.800.000 & 4 & 3,22 & Sedang \\
\hline 22 & 78,22 & Rp1.450.000 & 4 & 3,2 & Sedang \\
\hline 23 & 78,3 & Rp800.000 & 3 & 3,16 & Sedang \\
\hline 24 & 78,04 & Rp925.000 & 3 & 3,11 & Sedang \\
\hline 25 & 77,43 & Rp1.800.000 & 4 & 2,96 & Sedang \\
\hline 26 & 78,96 & Rp1.300.000 & 2 & 3,37 & Sedang \\
\hline 27 & 77,48 & Rp1.700.000 & 3 & 2,94 & Sedang \\
\hline
\end{tabular}

Hasil perangkingan pada hasil dari Tabel 10, dapat dilihat padaTabel 11. 
Tabel 11. Hasil Perangkingan

\begin{tabular}{|c|c|c|c|c|c|c|}
\hline \multirow[b]{2}{*}{ NO } & \multirow[b]{2}{*}{$\begin{array}{l}\text { NAMA } \\
\text { SISWA }\end{array}$} & \multicolumn{3}{|c|}{ VARIABEL INPUT } & \multirow[b]{2}{*}{$\begin{array}{c}\text { NILAI Z } \\
\text { MAMDANI }\end{array}$} & \multirow[b]{2}{*}{ HASIL } \\
\hline & & $\begin{array}{c}\text { RATA- } \\
\text { RATA } \\
\text { NILAI } \\
\text { RAPOR }\end{array}$ & PENDAPATAN & $\begin{array}{c}\text { JUMLAH } \\
\text { TANGGUN } \\
\text { GAN } \\
\text { ORANG } \\
\text { TUA } \\
\end{array}$ & & \\
\hline 1 & 20 & 80,52 & Rp1.500.000 & 2 & 4,38 & Tinggi \\
\hline 2 & 26 & 78,96 & Rp1.300.000 & 2 & 3,37 & Sedang \\
\hline 3 & 21 & 78,3 & Rp1.800.000 & 4 & 3,22 & Sedang \\
\hline 4 & 22 & 78,22 & Rp1.450.000 & 4 & 3,2 & Sedang \\
\hline 5 & 23 & 78,3 & Rp800.000 & 3 & 3,16 & Sedang \\
\hline 6 & 18 & 78,3 & Rp1.100.000 & 3 & 3,13 & Sedang \\
\hline 7 & 24 & 78,04 & Rp925.000 & 3 & 3,11 & Sedang \\
\hline 8 & 25 & 77,43 & Rp1.800.000 & 4 & 2,96 & Sedang \\
\hline 9 & 27 & 77,48 & Rp1.700.000 & 3 & 2,94 & Sedang \\
\hline 10 & 4 & 76,96 & Rp2.000.000 & 4 & 2,78 & Sedang \\
\hline 11 & 17 & 76,48 & Rp1.500.000 & 3 & 2,78 & Sedang \\
\hline 12 & 6 & 76,7 & Rp1.750.000 & 2 & 2,74 & Sedang \\
\hline 13 & 7 & 75,09 & Rp1.250.000 & 5 & 2,56 & Sedang \\
\hline 14 & 8 & 75,13 & Rp2.200.000 & 6 & 2,49 & Rendah \\
\hline 15 & 13 & 75,22 & Rp1.850.000 & 6 & 2,49 & Rendah \\
\hline 16 & 16 & 75,22 & Rp800.000 & 2 & 2,49 & Rendah \\
\hline 17 & 19 & 75,09 & Rp2.000.000 & 4 & 2,47 & Rendah \\
\hline 18 & 15 & 74,3 & Rp2.500.000 & 2 & 2,4 & Rendah \\
\hline 19 & 1 & 74,17 & Rp1.000.000 & 3 & 2,31 & Rendah \\
\hline 20 & 5 & 73,78 & Rp1.100.000 & 4 & 2,25 & Rendah \\
\hline 21 & 2 & 72,96 & Rp1.290.000 & 2 & 1,62 & Rendah \\
\hline 22 & 10 & 71,3 & Rp1.500.000 & 2 & 1,62 & Rendah \\
\hline 23 & 12 & 71,57 & Rp900.000 & 4 & 1,62 & Rendah \\
\hline 24 & 11 & 72,78 & Rp1.000.000 & 3 & 1,57 & Rendah \\
\hline 25 & 3 & 72,87 & Rp1.400.000 & 5 & 1,55 & Rendah \\
\hline 26 & 9 & 72,75 & Rp3.000.000 & 3 & 1,54 & Rendah \\
\hline 27 & 14 & 70,22 & Rp2.900.000 & 3 & 1,52 & Rendah \\
\hline
\end{tabular}

Jika dibandingkan dengan metode yang digunakan SMAN 1 Parung yang hanya melakukanpenentuan beasiswa melalui rata-rata nilai rapor tanpa menggabungkan aspek lain maka dapat dilihat pada Tabel 12. 
Tabel 12. Hasil Perbandingan Penentuan Beasiswa antara Metode Centroid dan SMAN 1 Parung

\begin{tabular}{|c|c|c|c|c|c|}
\hline \multirow[b]{2}{*}{$\begin{array}{l}\text { Nama } \\
\text { Siswa }\end{array}$} & \multicolumn{4}{|c|}{ SMAN 1 Parung } & \multirow[b]{2}{*}{$\begin{array}{c}\text { Nilai Z } \\
\text { Mamdani }\end{array}$} \\
\hline & $\begin{array}{l}\text { Rata- } \\
\text { rata } \\
\text { Nilai } \\
\text { Rapor }\end{array}$ & Pendapatan & $\begin{array}{c}\text { Tanggungan } \\
\text { Orang tua }\end{array}$ & $\begin{array}{c}\text { Hanya } \\
\text { menggunakan } \\
\text { nilai rapor }\end{array}$ & \\
\hline 1 & 74,17 & Rp1.000.000 & 3 & Ditolak & Ditolak \\
\hline 2 & 72,96 & Rp1.290.000 & 2 & Ditolak & Ditolak \\
\hline 3 & 72,87 & Rp1.400.000 & 5 & Ditolak & Ditolak \\
\hline 4 & 76,96 & Rp2.000.000 & 4 & Diterima & Diterima \\
\hline 5 & 73,78 & Rp1.100.000 & 4 & Ditolak & Ditolak \\
\hline 6 & 76,7 & Rp1.750.000 & 2 & Diterima & Ditolak \\
\hline 7 & 75,09 & Rp1.250.000 & 5 & Ditolak & Ditolak \\
\hline 8 & 75,13 & Rp2.200.000 & 7 & Ditolak & Ditolak \\
\hline 9 & 72,75 & Rp3.000.000 & 3 & Ditolak & Ditolak \\
\hline 10 & 71,3 & Rp1.500.000 & 2 & Ditolak & Ditolak \\
\hline 11 & 72,78 & Rp1.000.000 & 3 & Ditolak & Ditolak \\
\hline 12 & 71,57 & Rp900.000 & 4 & Ditolak & Ditolak \\
\hline 13 & 75,22 & Rp1.850.000 & 6 & Ditolak & Ditolak \\
\hline 14 & 70,22 & Rp2.900.000 & 3 & Ditolak & Ditolak \\
\hline 15 & 74,3 & Rp2.500.000 & 2 & Ditolak & Ditolak \\
\hline 16 & 75,22 & Rp600.000 & 4 & Ditolak & Ditolak \\
\hline 17 & 76,48 & Rp1.500.000 & 3 & Ditolak & Diterima \\
\hline 18 & 78,3 & Rp1.100.000 & 4 & Diterima & Diterima \\
\hline 19 & 75,09 & Rp2.000.000 & 4 & Ditolak & Ditolak \\
\hline 20 & 80,52 & Rp1.500.000 & 2 & Diterima & Diterima \\
\hline 21 & 78,3 & Rp1.800.000 & 5 & Diterima & Diterima \\
\hline 22 & 78,22 & Rp1.450.000 & 4 & Diterima & Diterima \\
\hline 23 & 78,3 & Rp800.000 & 4 & Diterima & Diterima \\
\hline 24 & 78,04 & Rp925.000 & 3 & Diterima & Diterima \\
\hline 25 & 77,43 & Rp1.800.000 & 4 & Diterima & Diterima \\
\hline 26 & 78,96 & Rp1.300.000 & 2 & Diterima & Diterima \\
\hline 27 & 77,48 & Rp1.700.000 & 3 & Diterima & Diterima \\
\hline
\end{tabular}

Perbandingan hasil yang dilakukan sekolah dengan menggunakan metode fuzzy Mamdani menghasilkan hasil yang berbeda. Metode yang dilakukan sekolah menghasilkan 11 orang yang layak mendapatkan beasiswa, sedangkan metode fuzzy Mamdani menghasilkan satu orang yang layak menerima beasiswa.

\subsection{Penyelesaian Masalah Menggunakan Matlab}

Berikut ini dijelaskan implementasi dari kasus yang telah dijelaskan sebelumnya dengan menggunakan Fuzzy Logic Toolbox Matlab yang disajikan pada Gambar 11. 


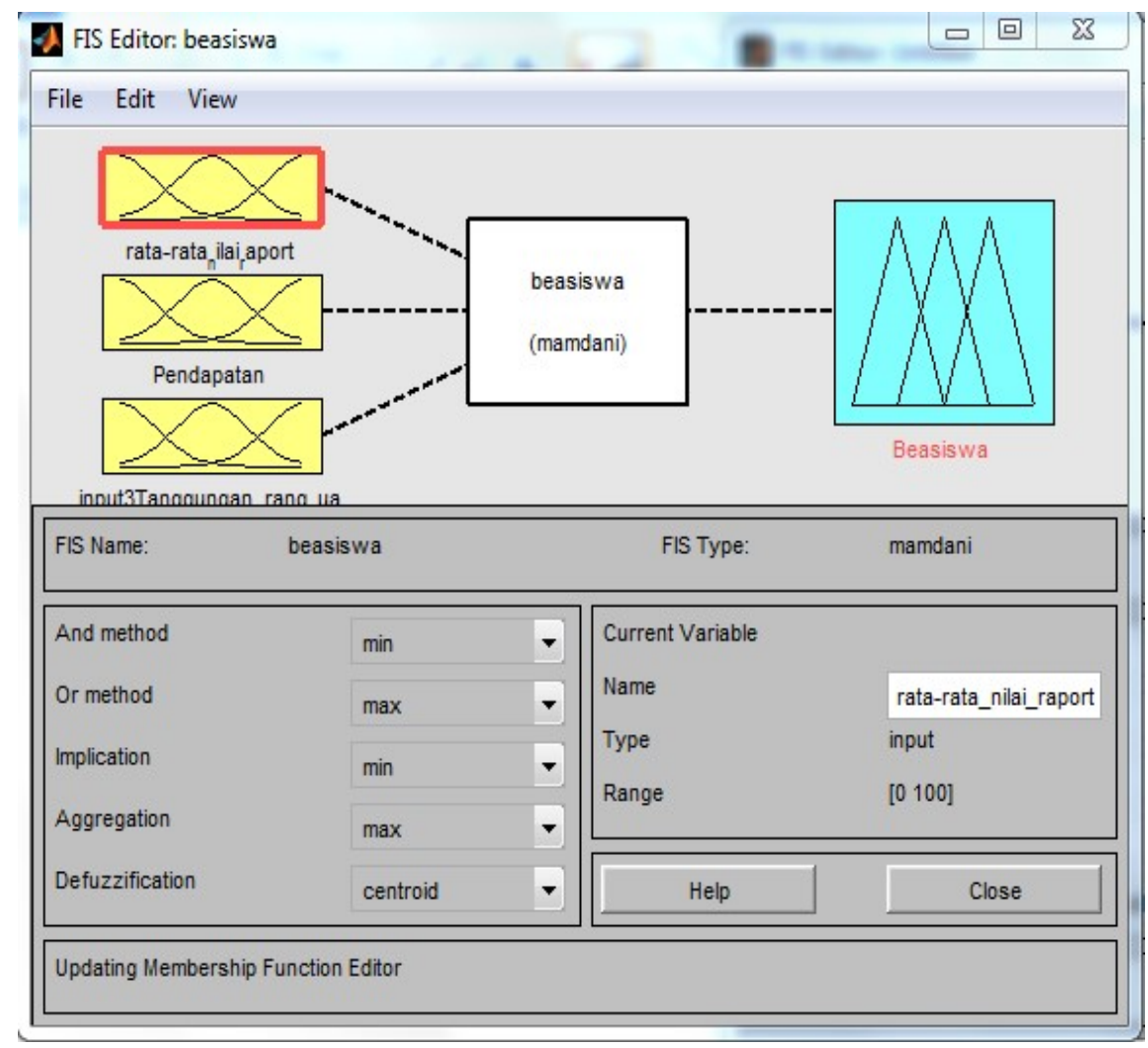

Gambar 11. Fuzzy Inference System Editor

Pada Gambar 11, terdapat tiga variabel input yaitu rata-rata nilai rapor, pendapatan, tanggungan orang tua dan satu variabel output yaitu beasiswa. Akses langsung terhadap setiap variabel dapat ditekan atau klik dua kali langsung pada masing-masing kotak variabel. Tampilan fungsi keanggotaan variabel rata-rata nilai rapor disajikan pada Gambar 12.

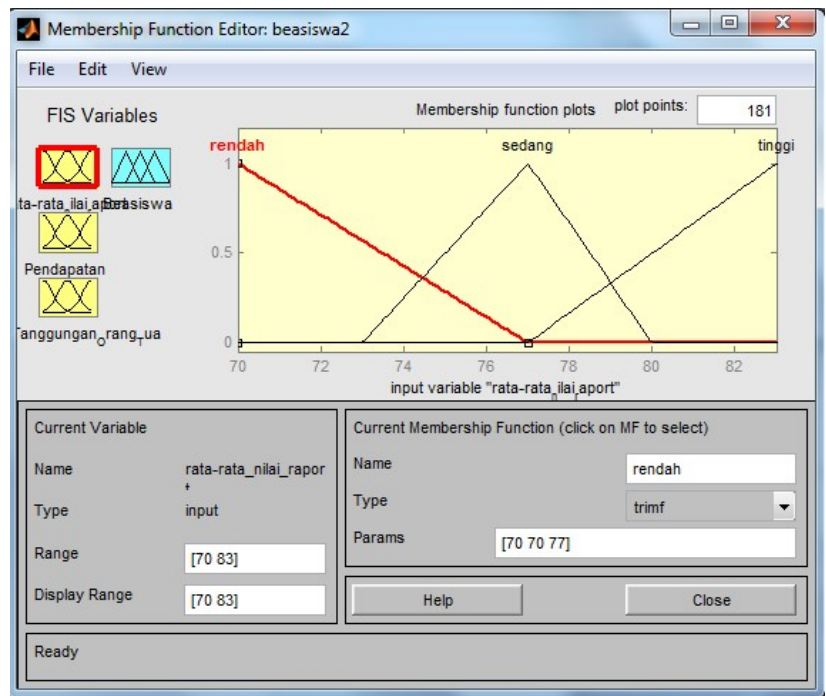

Gambar 12. Tampilan Fungsi Keanggotaan Variabel Rata-Rata Nilai Rapor 
Gambar 12 menampilkan fungsi keanggotaan untuk variabel rata-rata nilai rapor, dengan nilai linguistik rendah, sedang, dan tinggi dengan parameter yang berbeda. Selain itu, tampilan fungsi keanggotaan untuk variabel pendapatan orang tua disajikan pada Gambar 13.

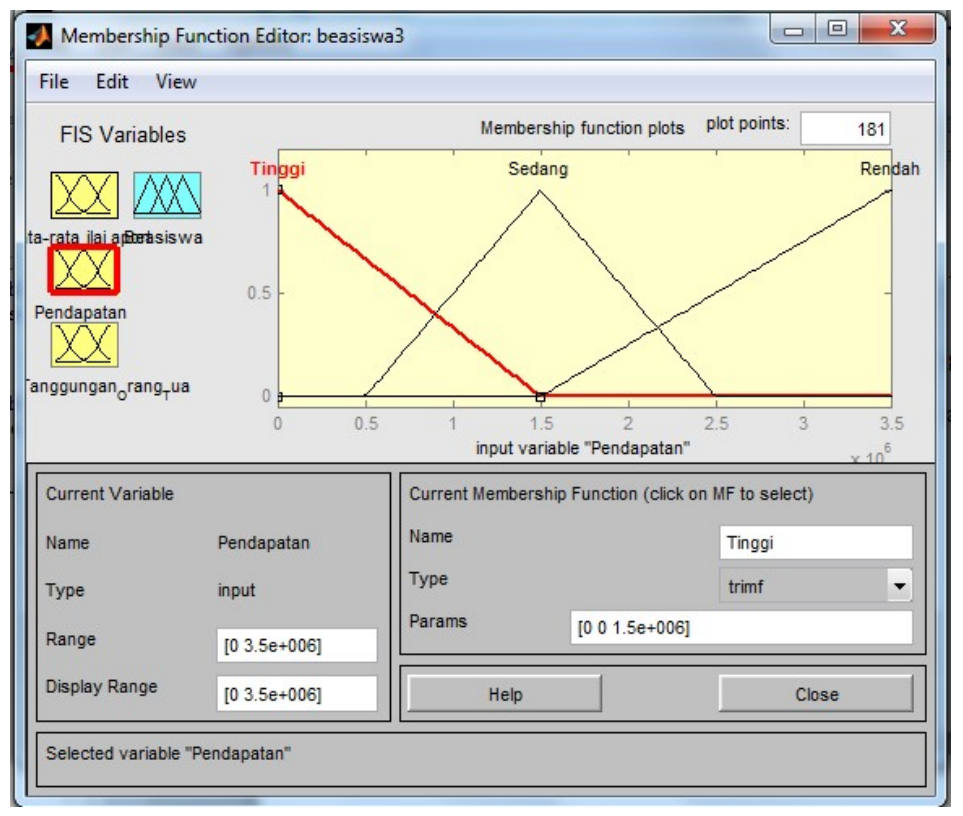

Gambar 13. Tampilan Fungsi Keanggotaan Variabel Pendapatan Orang tua

Gambar 13 menampilkan fungsi keanggotaan untuk variabel pendapatan, dengan nilai linguistik rendah, sedang, dan tinggi dengan parameter yang berbeda. Selanjutnya, tampilan fungsi keanggotaan variabel tanggungan orang tua disajikan pada Gambar 14.

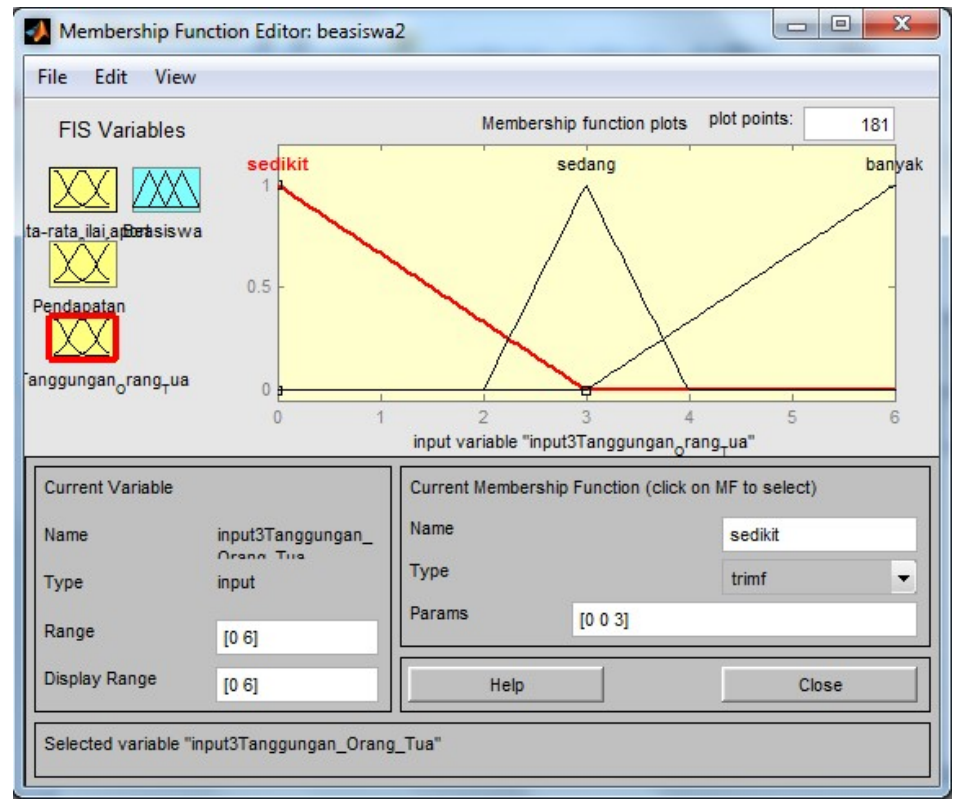

Gambar 14. Tampilan Fungsi Keanggotaan Variabel Jumlah Tanggungan Orang Tua 
Gambar 14 menampilkan fungsi keanggotaan untuk variabel tanggungan orang tua, dengan nilai linguistik sedikit, sedang, dan banyak dengan parameter yang berbeda. Selain itu, tampilan fungsi keanggotaan dari variabel beasiswa disajikan pada Gambar 15.

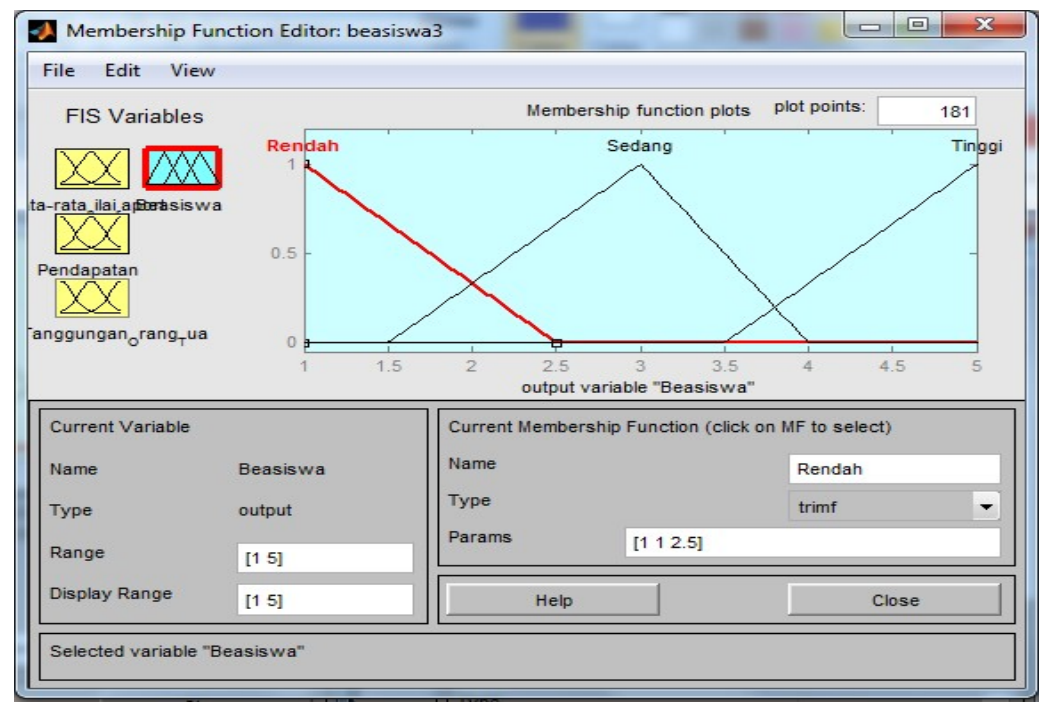

Gambar 15. Tampilan Fungsi Keanggotaan Variabel Beasiswa

Gambar 15 menampilkan fungsi keanggotaan untuk variabel beasiswa, dengan nilai linguistik rendah, sedang dan tinggi dengan parameter yang berbeda.Gambaran mengenai aturan metode Mamdani beasiswa disajikan pada Gambar 16.

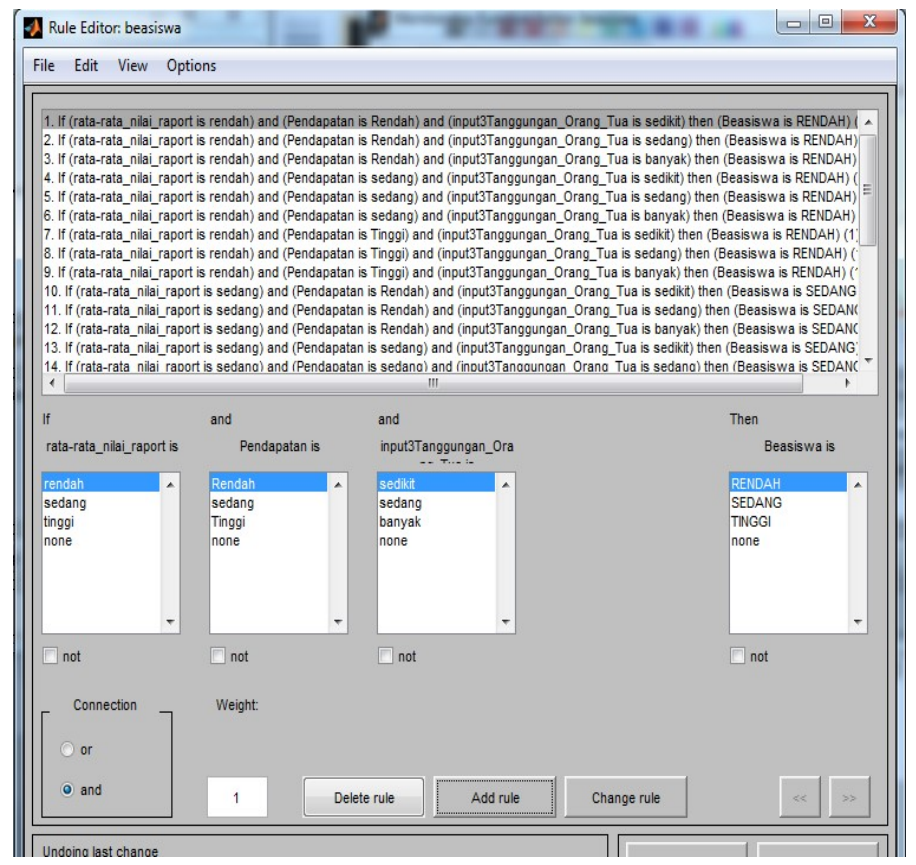

Gambar 16. Tampilan Editor Aturan Metode Mamdani Beasiswa

Gambar 16. menampilkan komposisi aturan untuk variabel beasiswa, dengan nilai linguistik rendah, sedang dan tinggi dengan operator and. Berdasarkan aturan metode Mamdani yang telah dibuat, maka dapat diketahui tampilan komposisi aturan yang disajikan pada Gambar 17. 
Munawaroh, Normalisa, Alvino Octaviano.

Analisa dan Penerapan Fuzzy Inference System Metode Mamdani untuk Penentuan Penerima Beasiswa.

International Journal of Artificial Intelligence, vol. 6, no. 1, pp. 21-52, June 2019. DOI: 10.36079/lamintang.ijai-0601.31

Gambar 17 menampilkan komposisi masing-masing variabel dengan masukan yang dapat dilihat pada kotak input yang berwarna kuning. Hasil keluarannya terletak pada kotak yang paling kanan dan berwarna biru. Hasil keluaran dapat langsung ditampilkan berdasarkan input yang dimasukkan.

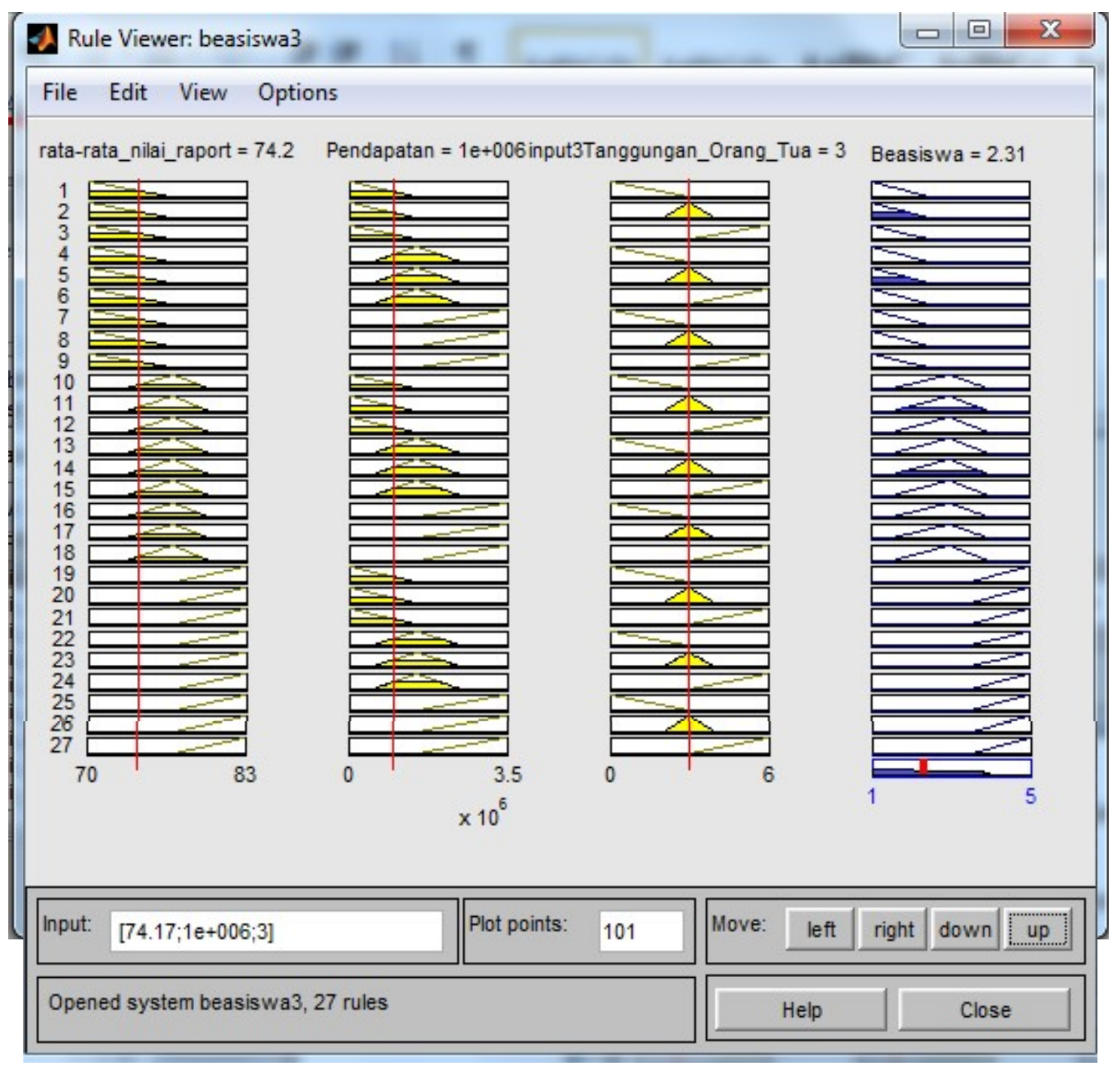

Gambar 17. Tampilan Komposisi Aturan

Hasil akhir menampilkan angka yang merupakan persentase penerimaan beasiswa. Selain itu, tampilan diagram metode Mamdani beasiswa dapat dilihat pada Gambar 18. 


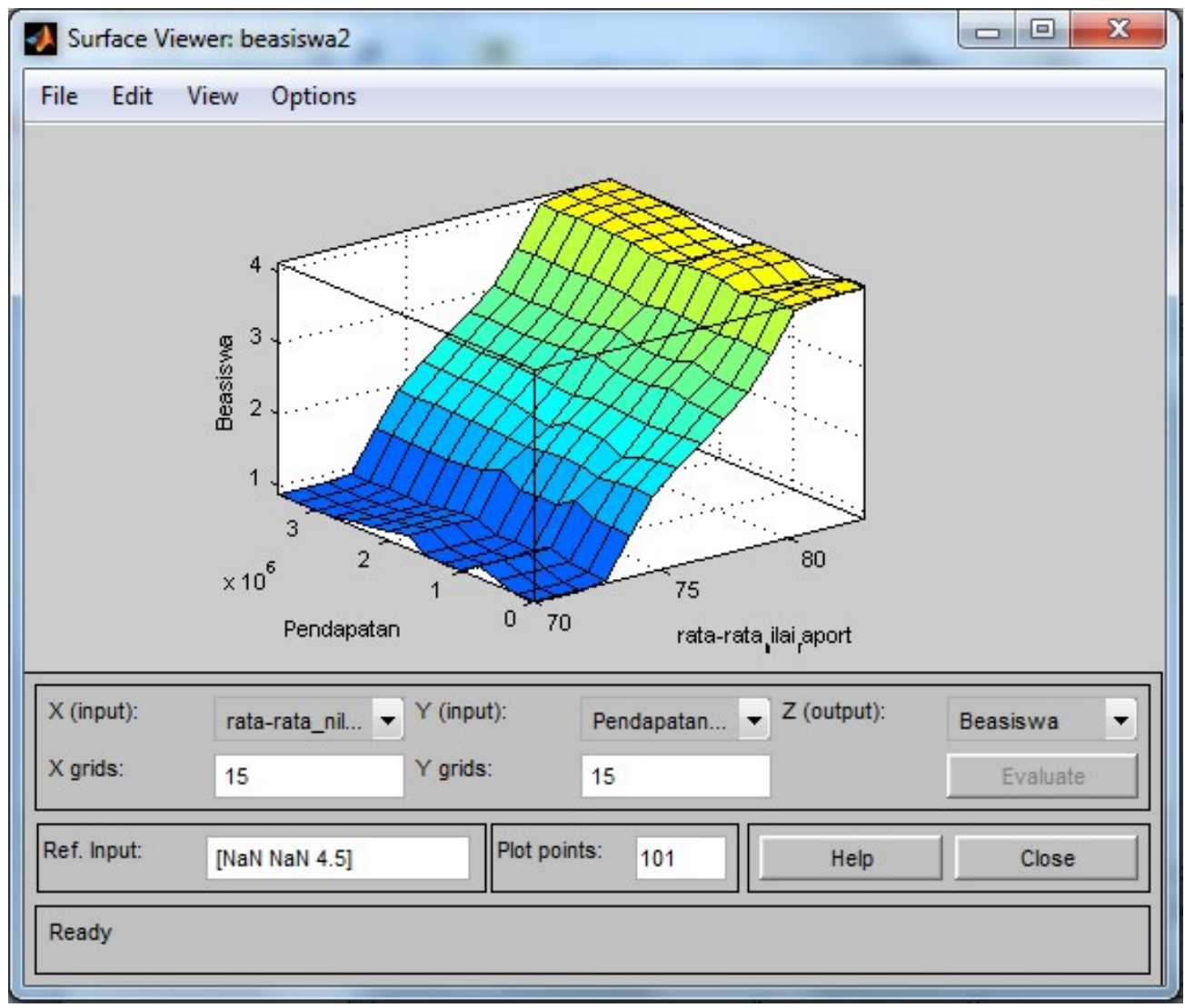

Gambar 18. Tampilan Diagram Metode Mamdani Beasiswa

Gambar 18. Menampilkan komposisi masing-masing variabel dengan masukan yang telah dilakukan sebelumnya. Tampilan berupa grafik dengan sumbu X dan sumbu Y sebagai masukannya dan sumbu $\mathrm{Z}$ sebagai keluarannya yang dapat memberikan informasi tentang perbandingan variabel yang dibandingkan dan keluarannya.

\section{Kesimpulan}

Perhitungan penentuan beasiswa dengan menggunakan metode Mamdani melalui logika fuzzy terdiri dari empat tahap yaitu pembentukan himpunan fuzzy, aplikasi fungsi implikasi dengan fungsi MIN, komposisi aturan dengan fungsi MAX, dan defuzzfikasi dengan metode centroid.

Setelah dilakukan perbandingan hasil melalui metode centroid dengan menggunakan rata-rata nilai rapor, maka terdapat 1 orang yang seharusnya layak menerima beasiswa yaitu siswa nomor 17 yang mempunyai rata-rata nilai rapor 76,48. Namun demikian, siswa tersebut tidak mendapatkan beasiswa dikarenakan nilai rata-rata rapor mempunyai selisih 0,3 dari siswa nomor 6 yang mempunyai rata-rata nilai rapor 76,7. Berdasarkan pembahasan tersebut dapat diambil kesimpulan bahwa:

1. Penentuan penerima beasiswa dengan menggunakan fuzzy inference system metode Mamdani dapat menghasilkan daftar siswa-siswi yang layak dan tepat sasaran.

2. Menggunakan perhitungan fuzzy inference system metode Mamdani dapat menentukan penerima beasiswa secara tepat dan akurat

\section{Daftar Pustaka}

[1] H. Anshari, Pengantar Ilmu Pendidikan. Surabaya: Usaha Nasional, 1983.

[2] H. Wibowo, R. Amalia, A. M. Fadlun, and K. Arivanty, "Sistem Pendukung Keputusan untuk Menentukan Penerima Beasiswa Bank BRI Menggunakan FMADM (Studi Kasus: Mahasiswa Fakultas Teknologi Industri Universitas Islam Indonesia)," Dalam Seminar Nasional Aplikasi Teknologi Informasi 2009, Yogyakarta, Juni 2009. 
Munawaroh, Normalisa, Alvino Octaviano.

Analisa dan Penerapan Fuzzy Inference System Metode Mamdani untuk Penentuan Penerima Beasiswa.

International Journal of Artificial Intelligence, vol. 6, no. 1, pp. 21-52, June 2019. DOI: 10.36079/lamintang.ijai-0601.31

[3] S. Kusumadewi, "Pencarian Bobot Atribut pada Multiple Atribut Decision Making (MADM) dengan Pendekatan Obyektif Menggunakan Algoritma Genetik," Dalam Seminar Nasional Pendidikan Teknik Elektro, Yogyakarta, Desember 2004.

[4] Hafsah, H. C. Rustamaji, and Y. Inayati, "Sistem Pendukung Keputusan Pemilihan Jurusan di SMU dengan Logika Fuzzy," in Seminar Nasional Informatika 2008, Yogyakarta: UPN Veteran, Mei 2008.

[5] N. Agus, "Belajar Cepat Fuzzy Logic Menggunakan Matlab," Yogyakarta: Andi, 2009.

[6] Zimmerman, Fuzzy Set Theory an Its Application. Massachusetss: Kluwer Academic Publisher, 1991.

[7] C. Earl, The Fuzzy System handbook. Massachusetts: Academic Press - Inc., 1994.

[8] S. Kusumadewi, Analisis \& Desain System Fuzzy (Menggunakan Toolbox Matlab). Yogyakarta: Graha Ilmu", 2002.

[9] T. Roses, Fuzzy Logic with Engineering Applications. Wiley: University of New Mexico, USA, 2010.

[10] A. Muhammad, and A. Desiani, Pemrograman Matlab. Yogyakarta: Andi, 2008. 